\title{
AMPK and Pulmonary Hypertension: Crossroads Between Vasoconstriction and Vascular Remodeling
}

\author{
Qiang Zhao, Ping Song and Ming-Hui Zou* \\ Center for Molecular and Translational Medicine, Georgia State University, Atlanta, GA, United States
}

Pulmonary hypertension $(\mathrm{PH})$ is a debilitating and life-threatening disease characterized by increased blood pressure within the pulmonary arteries. Adenosine monophosphateactivated protein kinase (AMPK) is a heterotrimeric serine-threonine kinase that contributes to the regulation of metabolic and redox signaling pathways. It has key roles in the regulation of cell survival and proliferation. The role of AMPK in $\mathrm{PH}$ is controversial because both inhibition and activation of AMPK are preventive against $\mathrm{PH}$ development. Some clinical studies found that metformin, the first-line antidiabetic drug and the canonical AMPK activator, has therapeutic efficacy during treatment of earlystage $\mathrm{PH}$. Other study findings suggest the use of metformin is preferentially beneficial for treatment of $\mathrm{PH}$ associated with heart failure with preserved ejection fraction $(\mathrm{PH}-$ HFpEF). In this review, we discuss the "AMPK paradox" and highlight the differential effects of AMPK on pulmonary vasoconstriction and pulmonary vascular remodeling. We also review the effects of AMPK activators and inhibitors on rescue of preexisting $\mathrm{PH}$ in animals and include a discussion of gender differences in the response to metformin in $\mathrm{PH}$. Keywords: AMPK, pulmonary hypertension, pulmonary vascular remodeling, hypoxic pulmonary
vasoconstriction, metformin mzou@gsuedu

\section{INTRODUCTION}

Pulmonary hypertension (PH) is a disease characterized by high blood pressure that affects the vessels in lungs. These changes result in right ventricular failure and ultimately, premature death (Maron and Leopold, 2015). Adenosine monophosphate-activated protein kinase (AMPK) is a central regulator of energy homeostasis. It is activated under a variety of conditions, including hypoxia, nutrient starvation, and toxin exposure (Towler and Hardie, 2007; Kim et al., 2016; Herzig and Shaw, 2018). AMPK exerts most of its biological effects via catalytic $\alpha$-subunits ( $\alpha 1$ and $\alpha 2)$ that are ubiquitously expressed in pulmonary vessels (Mihaylova and Shaw, 2011; Hardie, 2013; Kim et al., 2016). AMPK $\alpha 1$ is the predominant subunit in small pulmonary artery-derived pulmonary microvascular endothelial cells (ECs) and vascular smooth muscle cells (VSMCs). AMPK $\alpha 2$ is the predominant subunit in conduit pulmonary artery-derived ECs and VSMCs (Evans et al., 2005; Creighton et al., 2011). The AMPK $\alpha 1$ and AMPK $\alpha 2$ subunits have different effects on survival of pulmonary VSMCs and hypoxic pulmonary vasoconstriction. For example, activation of AMPK $\alpha 1$ stimulates autophagy in pulmonary artery VSMCs, but AMPK $\alpha 2$ activation prevents apoptosis 
(Ibe et al., 2013). Under conditions of mild hypoxia, AMPK $\alpha 1$ is activated by liver kinase B1 (LKB1) and is required for hypoxic pulmonary vasoconstriction; the AMPK $\alpha 2$ subunit is required under conditions of severe hypoxia (Moral-Sanz et al., 2018). Because of these characteristics, studies found that use of AMPK-targeting agonists and antagonists results in contradictory effects on PH development. Some studies found that AMPK activators [i.e., metformin (Agard et al., 2009; Dean et al., 2016; Lai et al., 2016; Omura et al., 2016; Zhai et al., 2018; Zhang et al., 2018; Wang et al., 2020), 5-aminoimidazole4-carboxamide (AICAR) (Huang et al., 2014; Chen et al., 2016; Dean et al., 2016), rosiglitazone/pioglitazone (Hansmann et al., 2007; Satoh et al., 2009; Kim et al., 2010; Legchenko et al., 2018), and apelin (Chandra et al., 2011; Kim, 2014)] are protective against experimental PH. Other studies found that AMPK activation induces hypoxic pulmonary vasoconstriction (Evans, 2006; Robertson et al., 2008; Evans et al., 2009; Moral-Sanz et al., 2018) and that inhibition of AMPK by compound C prevents PH (Ibe et al., 2013). Results from human clinical studies are not currently conclusive on the precise role of AMPK in PH because studies on $\mathrm{PH}$ treatment using metformin are currently phase two clinical trials (NCT01884051 and NCT03629340). The AMPK paradox remains relevant.

\section{AMPK: STRUCTURE AND REGULATION}

\section{AMPK Structure}

Adenosine monophosphate-activated protein kinase is a highly conserved serine/threonine protein kinase complex consisting of a catalytic $\alpha$-subunit, a scaffolding $\beta$-subunit, and a regulatory $\gamma$-subunit (Figure 1). In eukaryotes, each subunit has multiple distinct isoforms encoded by different genes. The $\alpha$-subunit has two isoforms, $\alpha 1$ and $\alpha 2$, encoded by genes Prkaal and Prkaa2, respectively (Stapleton et al., 1996). It contains a canonical N-terminal Ser/Thr kinase domain (KD), an autoinhibitory domain (AID), and an adenine nucleotide sensor segment termed an $\alpha$-linker (Herzig and Shaw, 2018; Yan et al., 2018). AMPK activation requires phosphorylation of critical residues (Thr174 in the AMPK $\alpha 1$ subunit and Thr172 in the AMPK $\alpha 2$ subunit) within the activation loop of the KD in the $\mathrm{AMPK} \alpha$ catalytic subunit that is phosphorylated by upstream kinases LKB1 (Hudson et al., 2003), $\mathrm{Ca}^{2+/}$ calmodulin-dependent protein kinase $\beta$ (CaMKK $\beta$ ) (Woods et al., 2005), or TGF-betaactivated kinase-1 (TAK-1) (Momcilovic et al., 2006). AMPK auto-inhibition requires an AID, which interacts with the KD and causes AMPK to be maintained as an inactive conformation (Chen et al., 2013; Kim et al., 2016). The $\beta$-subunit also has two isoforms, $\beta 1$ and $\beta 2$, encoded by Prkab1 and Prkab2, respectively (Hudson et al., 2003). The $\gamma$-subunit has three isoforms, $\gamma 1$, $\gamma 2$, and $\gamma 3$, encoded by Prkag1, Prkag2, and Prkag3, respectively (Cheung et al., 2000). The $\gamma$-subunits contain four tandem cystathionine- $\beta$-synthase domains, which enable AMP, ADP, or ATP binding (Xiao et al., 2007). Binding of AMP, and to a lesser extent ADP, to the $\gamma$-subunit is an important regulatory feature of the conformational switch that activates the AMPK complex (Hardie et al., 2011; Gowans et al., 2013; Ross et al., 2016a). Each
AMPK complex consists of one $\alpha$-subunit, one $\beta$-subunit, and one $\gamma$-subunit, and all 12 heterotrimeric combinations are possible (Ross et al., 2016b). Different subunits have distinct organ preferences and expression patterns. For example, the AMPK $\alpha 1$ subunit is mainly expressed in adipose tissue (Ruderman et al., 2003; Rutter et al., 2003; Kelly et al., 2004). The AMPK $\alpha 2$ subunit is predominantly expressed in skeletal muscle and cardiac myocytes (Sakamoto et al., 2005, 2006; Thomson et al., 2007). Isoform-specific roles of AMPK $\alpha 1 /$ AMPK $\alpha 2$ contribute to the pathogenesis of different diseases (e.g., cardiovascular disease (Ahmad et al., 2005; Sakamoto et al., 2006; Zarrinpashneh et al., 2006; Arad et al., 2007), osteoclastogenesis (Wang et al., 2016), and Alzheimer's disease (Zhao et al., 2020)).

\section{AMPK Signaling Transduction}

Adenosine monophosphate-activated protein kinase can be phosphorylated directly by small molecules that mimic cellular decreased ATP-to-ADP or ATP-to-AMP ratios or three upstream AMPK kinases (i.e., LKB1, CaMKK $\beta$ and TAK1) (Figure 1). Upon changes in ATP/ADP and ATP/AMP ratios that occur during nutrient starvation, AMP binds to the AMPK $\gamma$ subunit to cause allosteric activation via modulation of the phosphorylation state of Thr172 (Xiao et al., 2011; Oakhill et al., 2012; Gowans et al., 2013). LKB1, in a complex with the pseudokinase STRAD and the scaffolding protein MO25, directly phosphorylates AMPK at Thr172 (Lizcano et al., 2004). Study results indicate that LKB1 is the principal route via which AMPK is activated in many organs (e.g., skeletal muscle, adipose tissue, and liver) (Shackelford and Shaw, 2009). Whereas, CaMKK $\beta$ activates AMPK in response to $\mathrm{Ca}^{2+}$ signaling pathways (Hawley et al., 2005; Hong et al., 2005; Hurley et al., 2005). In 2006, TAK1 (i.e., MAPKK kinase-7, MAP3K7) was identified as the third kinase capable of direct AMPK activation (Momcilovic et al., 2006).

Adenosine monophosphate-activated protein kinase can be activated by hypoxia in various tissue and cell types (Mungai et al., 2011; Sallé-Lefort et al., 2016), but long-term hypoxia exposure inhibits AMPK activation (de Theije et al., 2018). Many studies found that activation of AMPK under hypoxia primarily implies LKB1 activity, because AMPK activation is abrogated in LKB1-deleted cells and knockout of CaMKK2, or another upstream kinase, has no effect on AMPK activation in VSMCs under hypoxic conditions (Moral-Sanz et al., 2018). Some studies found that LKB1 seems to only activate the AMPK $\alpha 2$ subunit, because the AMPK $\alpha 1$ subunit remains phosphorylated in LKB1-deficient heart muscle cells (Sakamoto et al., 2006). This result might be explained by differences in abundances and preferences of the AMPK upstream kinase in different cells and organs. Increased production of reactive oxygen species (ROS) in hypoxic conditions contributes to activation of AMPK (Choi et al., 2001; Emerling et al., 2009; Zmijewski et al., 2010; Hinchy et al., 2018). Hypoxia-inducible factor-prolyl-4hydroxylases (HIF-P4Hs) have a role in the activation of AMPK (Yan et al., 2012; Dengler and Gäbel, 2019).

Once activated, AMPK phosphorylates key proteins in multiple pathways (Marsin et al., 2000; Inoki et al., 2003; 




FIGURE 1 | Summary of AMP-activated protein kinase (AMPK) structure and activation. Domain structure of AMPK trimer: $\alpha$-, $\beta$-, and $\gamma$-subunits with respective domains. AMPK $\alpha$ subunits: KD, kinase domain containing Thr-172 phosphorylation site; AID, autoinhibitory domain; BD, binding domain. AMPK $\beta$ subunits: CBM, carbohydrate binding module; BD, binding domain. AMPK $\gamma$ subunits: CBS, cystathione- $\beta$-synthase domain. The upstream kinases LKB1, CAMKK2, and TAK1 are shown above the AMPK complex. LKB1 in complex with STRAD and MO25 activates AMPK; CAMKK2 activated by intracellular calcium.

Gwinn et al., 2008) or directly regulates key enzymes involved in these pathways. These processes occur over time via targeting of transcriptional regulators (Koo et al., 2005; Lamia et al., 2009; Bungard et al., 2010; Figure 1). The most important aspect of AMPK biology is its role in maintaining the balance between catabolism and anabolism in response to metabolic stress (Towler and Hardie, 2007; Hardie, 2008; Fogarty and Hardie, 2010). Studies have revealed the roles of AMPK in lipid homeostasis [e.g., acetyl-CoA carboxylase (Munday et al., 1988) and HMGCoA reductase (Carling et al., 1987)], glucose metabolism [e.g., thioredoxin-interacting protein (TXNIP) (Wu et al., 2013) and 6-phosphofructo-2-kinase (Bando et al., 2005)], insulin signaling (Galic et al., 2011; Li Y. et al., 2011; Fullerton et al., 2013; Wu et al., 2015; Emilio et al., 2016; Myers et al., 2017), and food intake and body weight (Kahn et al., 2005; Kola et al., 2005; Kola, 2008). Given those functional attributes in metabolism, AMPK is a major therapeutic target for treatment of metabolic diseases (e.g., type 2 diabetes) and obesity (Viollet et al., 2009; Rojas et al., 2011; Hardie, 2013; Day et al., 2017). A growing body of evidence also points to specific regulation of AMPK and mitochondrial homeostasis, including via stimulation of mitochondrial biogenesis (Bergeron et al., 2001; Zong et al., 2002; Garcia-Roves et al., 2008), regulation of mitochondrial dynamics (Ducommun et al., 2015; Toyama et al., 2016), and mitophagy (Wang et al., 2001; Egan et al., 2011).

\section{AMPK and Cardiovascular Disease}

Adenosine monophosphate-activated protein kinase has pivotal roles in cardiovascular physiology and in cardiovascular disease states. AMPK $\alpha 1$ is the predominant subunit in VSMCs, ECs, monocytes/macrophages, and adipocytes. AMPK $\alpha 2$ is the predominant subunit in cardiomyocytes (Shirwany and Zou, 2010; Wu and Zou, 2020). The functions of AMPK in cardiovascular disease include contributions to atherosclerosis and to heart failure and hypertension, which have been extensively reviewed elsewhere (Shirwany and Zou, 2010; Wu and Zou, 2020).

\section{PULMONARY HYPERTENSION}

\section{Categories}

Pulmonary hypertension is a general term used to describe increased blood pressure (mean pulmonary arterial pressure, mPAP, exceeds $25 \mathrm{mmHg}$ at rest) in the lungs (Galiè et al., 2009). At the 5th and 6th World Symposium on PH, it was classified into five groups: pulmonary artery hypertension $\mathrm{PAH}$, Group 1), PH associated with left heart disease (Group 2), $\mathrm{PH}$ associated with lung disease and/or hypoxia (Group 3), $\mathrm{PH}$ associated with chronic thromboembolic disease (Group 4), and $\mathrm{PH}$ with unclear or multifactorial mechanisms, or both (Group 5) (Galiè and Simonneau, 2013; Simonneau et al., 2019). Each group represents a very broad spectrum of disease etiology, pathobiology, hemodynamic characteristics, and therapeutic approaches (Table 1). The detailed features and treatments of pulmonary hypertensive vascular disease in humans have been reviewed elsewhere (Maron and Galiè, 2016; Thenappan et al., 2018). AMPK deficiency has been identified in metabolic syndrome-associated PH (PH-HFpE) (Lai et al., 2016). However, in PAH, AMPK activity and expression can be either inhibited or promoted depending on cell type and branch pulmonary artery diameter (Ibe et al., 2013; Omura et al., 2016; Zhang et al., 2018), which is discussed in section "Clinical Trials of Pulmonary Hypertension Treatment Using Metformin.”

\section{Pathology of PH}

Although the exact causes of $\mathrm{PH}$ remain to be determined, study findings indicate that it results from a combination of sustained pulmonary vasoconstriction and pulmonary vascular remodeling (Stenmark and McMurtry, 2005; Stenmark et al., 2006). 
TABLE 1 | Animal models of pulmonary hypertension.

\begin{tabular}{|c|c|c|}
\hline Cause & Histological features & Animal models \\
\hline \multicolumn{3}{|c|}{ Group 1: Pulmonary arterial hypertension (PAH) } \\
\hline Idiopathic PAH & $\begin{array}{l}\text { Pulmonary artery intimal } \\
\text { proliferation }\end{array}$ & $\mathrm{Su}-\mathrm{H} \times \mathrm{rat} / \mathrm{mouse}$ \\
\hline Heritable PAH & $\begin{array}{l}\text { Pulmonary artery medical } \\
\text { hypertrophy }\end{array}$ & MCT rat \\
\hline Drugs/Toxin/Others & Plexiform lesions & Su-Hx-Normoxia \\
\hline \multicolumn{3}{|c|}{ Group 2: Pulmonary hypertension with left heart disease } \\
\hline \multirow[t]{3}{*}{ Left-sided heart disease } & $\begin{array}{l}\text { Pulmonary medical } \\
\text { hypertrophy }\end{array}$ & $\begin{array}{l}\text { SU5416/Obese } \\
\text { ZSF1 rat }\end{array}$ \\
\hline & $\begin{array}{l}\text { Pulmonary vein } \\
\text { arterialization }\end{array}$ & \\
\hline & $\begin{array}{l}\text { Pulmonary interstitial } \\
\text { edema }\end{array}$ & \\
\hline \multicolumn{3}{|c|}{ Group 3: Pulmonary hypertension associated with lung disease } \\
\hline High altitudes & $\begin{array}{l}\text { Hypoxic pulmonary } \\
\text { vasoconstriction }\end{array}$ & $\mathrm{Su}-\mathrm{H} \times \mathrm{rat} / \mathrm{mouse}$ \\
\hline COPD/Pulmonary fibrosis & Muscularization of arterioles & Hypoxia rat/mouse \\
\hline \multicolumn{3}{|l|}{ Obstructive sleep apnea } \\
\hline \multicolumn{3}{|c|}{$\begin{array}{l}\text { Group 4: Pulmonary hypertension due to chronic thrombotic and/or } \\
\text { embolic disease }\end{array}$} \\
\hline Pulmonary emboli & Thrombi or embolism & Vena cava ligation \\
\hline Other clotting disorders & $\begin{array}{l}\text { Recanalized organized } \\
\text { thrombi }\end{array}$ & \\
\hline \multicolumn{3}{|c|}{ Group 5: Pulmonary hypertension triggered by other health conditions } \\
\hline Heterogeneous & Heterogeneous & \\
\hline
\end{tabular}

Pulmonary vasoconstriction is the major contributor to the early phase of the disease; pulmonary vascular structural remodeling becomes progressively more dominant and important over time (Shimoda and Laurie, 2013). Hypoxic pulmonary vasoconstriction is a reflex contraction of vascular smooth muscle in the pulmonary circulation to optimize lung blood flow from low ventilated areas to well-oxygenated areas, and thereby optimize gas exchange and oxygen delivery (Moudgil et al., 2005; Dunham-Snary et al., 2017; Tarry and Powell, 2017). Unlike the systemic circulation, which dilates in the presence of hypoxia, pulmonary arteries constrict in response to alveolar hypoxia (Detar, 1980; Waypa and Schumacker, 2010). Hypoxic pulmonary vasoconstriction is an important homeostatic mechanism used to match regional perfusion and ventilation in the lung (Dunham-Snary et al., 2017; Tarry and Powell, 2017).

Sustained pulmonary vasoconstriction initiates pulmonary vascular structural changes. These changes are characterized by thickening of the intimal and/or medial layers of muscular vessels, which results in concentric pulmonary vascular remodeling (Heath and Edwards, 1958; Tuder, 2017). In human beings, pulmonary vascular remodeling is attributed to lesions that mainly occur in distal pre-capillary arteries, ranging in diameter from 500 to $700 \mu \mathrm{m}$. Remodeling involves a change in the maximal lumen diameter (interior and exterior) and accumulation of different vascular cell types in the pulmonary arterial wall (pulmonary artery ECs, VSMCs, and fibroblasts). Pulmonary endothelial dysfunction is the key trigger that drives
$\mathrm{PH}$ development. It is characterized by either impairment of endothelial-dependent vasodilatation, reduced anticoagulant properties, ROS production, or active EC metabolic changes (Budhiraja et al., 2004; Attinà et al., 2005; Klinger et al., 2013; Ranchoux et al., 2018). Various stimuli (e.g., hypoxia, smoking, disturbed blood flow, and oxidative stress) can lead to endothelial dysfunction (Dummer et al., 2018; Ranchoux et al., 2018). In PH, progressive accumulation of resident VSMCs in pulmonary arteries contributes to expansion of the tunica media. Accumulating evidence also supports involvement of increased VSMC proliferation and inhibition of apoptosis in pulmonary vascular medial layer thickening (Tuder et al., 2007; Lyle et al., 2017; Humbert et al., 2019). Better understanding of the molecular mechanisms underlying pulmonary endothelial dysfunction and VSMC adaptation will greatly enhance our understanding of the pathogenesis of $\mathrm{PH}$, which may help identify new therapeutic strategies. Other promising targets (e.g., fibroblast cell activation and immune system dysregulation) have also been identified as contributing to the pathogenesis of $\mathrm{PH}$ (Li M. et al., 2011; Rabinovitch et al., 2014; Plecitá-Hlavatá et al., 2016; Nicolls and Voelkel, 2017).

\section{Animal Models of PH}

A variety of pre-clinical $\mathrm{PH}$ animal models are available to study this complex disease of diverse etiologies and histopathological features. Each model has its own hemodynamic and microanatomic histological characteristics (Table 1). The chronic hypoxia rat/mouse model is the one most widely used to study $\mathrm{PH}$. Exposure of rats/mice to hypoxia causes increased mPAP, pulmonary vasoconstriction, and vascular medial hypertrophy that mimic the pathological features of human PH. However, right ventricular failure is absent (Zhao, 2010; Ryan et al., 2013). Monocrotaline (MCT) is a toxic alkaloid that causes a widespread pneumotoxicity and endothelial injury (Kay et al., 1967; Wilson et al., 1989). A single dose of MCT $(60 \mathrm{mg} / \mathrm{Kg})$ is sufficient to induce $\mathrm{PH}$ in rats by modulating two key pathological features of human $\mathrm{PH}$, pulmonary vascular remodeling and right ventricular failure (Schoental and Head, 1955; Jasmin et al., 2001; Dumitrascu et al., 2008; Gomez-Arroyo et al., 2012). Sugen 5416 is a vascular endothelial growth factor receptor 2 (VEGFR2) inhibitor. Sugen 5416/hypoxia ( $\mathrm{Su} / \mathrm{Hx}$ ) induces severe $\mathrm{PH}$ in both rats and mice that is characterized by pulmonary angioobliteration and right ventricular failure (Taraseviciene-Stewart et al., 2001; Sakao and Tatsumi, 2011). These three $\mathrm{PH}$ animal models are well-recognized models of Group 1 PH and Group 3 PH (Ryan et al., 2013; Colvin and Yeager, 2014; Sztuka and Jasiñska-Stroschein, 2017). Lai et al. (2016) developed a two-hit model of PH associated with heart failure with preserved ejection fraction $(\mathrm{PH}-\mathrm{HFpEF})$. It includes giving a single injection of SU5416 to obese ZSF1 rats. The SU5416/obese ZSF1 rats develop PH that includes a preserved ejection fraction and right and left ventricular hypertrophy. $\mathrm{PH}-\mathrm{HFpEF}$ develops as a more advanced corollary of $\mathrm{PH}$ and diastolic HF, leading to more severe symptoms than those with HFpEF and suffers significant exercise intolerance, frequent hospitalization, and reduced survival (Thenappan et al., 2011; Hoeper et al., 2016). 


\section{AMPK AND PULMONARY HYPERTENSION}

\section{Role of AMPK in the Predisposition and Development of PH}

Researches have revealed the role of AMPK in hypoxic pulmonary vasoconstriction and pulmonary vascular remodeling. Two clinical trials (NCT01884051 and NCT03629340) focusing on PAH treatment with metformin are in progress. However, in various animal models, AMPK has contradictory effects on $\mathrm{PH}$, as both inhibition and activation of AMPK are protective for the development of $\mathrm{PH}$. These seemingly opposing results can be partly explained by the different effects of AMPK signaling in pulmonary vasoconstriction and pulmonary vascular remodeling.

Role of AMPK in Hypoxic Pulmonary Vasoconstriction Until 1871, it was universally believed that the pulmonary vessels did not respond to a vasomotor system. However, Brown-Séquard (1871) published some results indicating that such a system exists. Subsequently, Bradford and Dean (1894) reported that asphyxia causes PH. von Euler and von Liljestrand (1946) reported that acute hypoxia promotes pulmonary vasoconstriction to increase pulmonary arterial pressure. This study (von Euler and von Liljestrand, 1946) launched the current era of study of hypoxia and pulmonary vasoconstriction.

Hypoxic pulmonary vasoconstriction is an important homeostatic physiological mechanism that optimizes ventilation/perfusion matching, gas exchange, and systemic oxygen delivery. In response to alveolar hypoxia, intrapulmonary arteries constrict to divert blood to better-oxygenated lung segments (Bradford and Dean, 1894; von Euler and von Liljestrand, 1946; McMurtry et al., 1976; Madden et al., 1985; Sylvester et al., 2012; Dunham-Snary et al., 2017). Hypoxic pulmonary vasoconstriction relies on a group of specialized pulmonary VSMCs, which are located in pulmonary arterial segments stripped of the tunica intima and tunica media, but not in similar segments of pulmonary veins or systemic arteries (Bergofsky et al., 1967; Murray et al., 1990a,b; Madden et al., 1992; Weir and Archer, 1995). Hypoxic pulmonary vasoconstriction is triggered by mitochondrial redox signaling that involves voltage-gated potassium channels $(\mathrm{Kv})$ and calcium channels (Weir and Archer, 1995). Hypoxia inhibits Kv channels in pulmonary VSMCs, causing membrane depolarization and opening of voltage-gated calcium channels to initiate $\mathrm{Ca}^{2+}$-mediated pulmonary vasoconstriction (Weir and Archer, 1995; Archer and Michelakis, 2002; Sommer et al., 2008; Dunham-Snary et al., 2017).

Adenosine monophosphate-activated protein kinase has a critical role in hypoxic pulmonary vasoconstriction by linking the oxygen sensor to its effectors (Figure 2). Evans et al. $(2005,2006)$ and Evans $(2006)$ found that physiological hypoxia increases the AMP/ATP ratio in pulmonary VSMCs, followed by increased AMPK activity and phosphorylation of a classical AMPK substrate, acetyl CoA carboxylase (a well-validated marker for AMPK activation). This process is likely to be mediated by binding of AMP to the AMPK $\gamma$ subunit, which triggers activation of the kinase by, (1) promoting AMPK Thr 172 phosphorylation via allosteric regulation (Scott et al., 2002; Kemp, 2004; Oakhill et al., 2010), (2) inhibiting AMPK Thr 172 dephosphorylating (Davies et al., 1995), and (3) facilitating phosphorylation of Thr 172 by the upstream kinase LKB1 (Hawley et al., 2003; Woods et al., 2003; Shaw et al., 2004, 2005). Additional studies found that AMPK activation evokes a slow, sustained, and reversible increase in $\mathrm{Ca}^{2+}$ influx via cyclic adenosine diphosphate-ribose (cADPR)-dependent mobilization of sarcoplasmic reticulum stores in pulmonary VSMCs and the consequent induction of constriction of pulmonary artery rings (Evans et al., 2005). Consistent with these findings, two different AMPK activators, AICAR and phenformin, evoke intracellular $\mathrm{Ca}^{2+}$ influx and reversible constriction of the pulmonary artery rings. The characteristics of this process are strikingly similar to those of hypoxic pulmonary vasoconstriction (Evans et al., 2005). The hypoxia-associated pulmonary vasoconstriction and $\mathrm{Ca}^{2+}$ influx is inhibited by the non-selective AMPK antagonist, compound $\mathrm{C}$, upon inhibition of the sarcoplasmic reticulum store-refilling current (Robertson et al., 2008). When hypoxia occurs, AMPK can directly phosphorylate voltage-gated potassium channels (Kv1.5 channels), followed by inhibition of $\mathrm{K}^{+}$currents in pulmonary VSMCs. The entry of voltagedependent $\mathrm{Ca}^{2+}$ to initiate the hypoxia-related pulmonary vasoconstriction is thus activated (Moral-Sanz et al., 2016). Downregulation of Kv1.5 expression and activity is also a hallmark of PH (Yuan et al., 1998; Lv et al., 2013). Strong support for this mechanism results from in vivo studies performed by Moral-Sanz et al. (2018), who found a key in vivo role of AMPK in hypoxic pulmonary vasoconstriction using a combination of AMPK isoform deletion strategies and spectral Doppler ultrasound. Under conditions of mild hypoxia $\left(8 \% \mathrm{O}_{2}\right)$, deletion of AMPK $\alpha 1$, but not AMPK $\alpha 2$, in smooth muscle cells block induction of hypoxia-related pulmonary vasoconstriction. When conditions of severe hypoxia $\left(5 \% \mathrm{O}_{2}\right)$ are present, either AMPK $\alpha 1$ or AMPK $\alpha 2$ deletion attenuates hypoxia-related pulmonary vasoconstriction (Moral-Sanz et al., 2018). The findings that SNPs in the Prkaal gene have been identified in populations that live at high altitudes and who have attenuated hypoxic pulmonary vasoconstriction are consistent with these results (Penaloza and Arias-Stella, 2007; Bigham et al., 2014). In summary, a growing body of evidence supports the hypothesis that AMPK activation is a primary mediator of hypoxic pulmonary vasoconstriction.

\section{Role of AMPK in Pulmonary Vasculature Remodeling}

In $\mathrm{PH}$, pulmonary arteries and veins undergo structure changes. This pulmonary vascular remodeling is characterized by proliferation of pulmonary ECs and VSMCs. AMPK has a key role in the pathogenesis of pulmonary vasculature remodeling (Figure 3).

\section{AMPK in Endothelial Cells and $P H$}

Both AMPK subunits (AMPK $\alpha 1$ and AMPK $\alpha 2$ ) are expressed in pulmonary ECs. However, AMPK $\alpha 1$ is mainly expressed in capillary-derived pulmonary microvascular ECs and AMPK $\alpha 2$ is mainly expressed in conduit-derived pulmonary artery ECs 


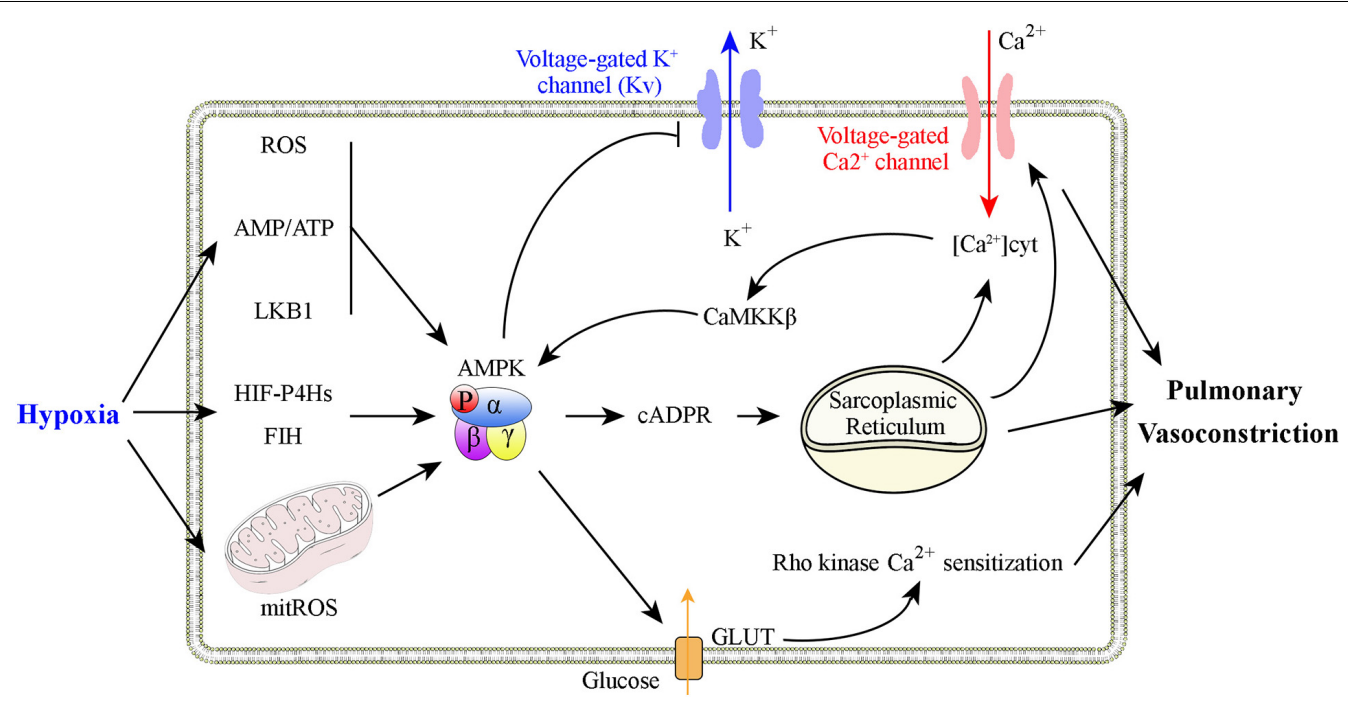

FIGURE 2 | Graphical summary of possible mechanisms that explain how AMPK activation is involved in hypoxic pulmonary vasoconstriction. Physiological hypoxia results in increases in the AMP/ATP ratio, ROS production, and in LKB1 activation to promote AMPK Thr 172 phosphorylation. AMPK activation increases Ca $2+$ levels in pulmonary VSMCs to promote constriction through, (1) inhibition of voltage-dependent $\mathrm{K}^{+}$channels, (2) activation of voltage-operated Ca ${ }^{2+}$ channels, and (3) activation of $\mathrm{Ca}^{2+}$-sensing sarcoplasmic reticulum.

(Creighton et al., 2011). Pulmonary endothelial AMPK is downregulated in pulmonary hypertensive patients and hypoxiainduced $\mathrm{PH}$ animals, compared with that from healthy donors or non-PH animals, respectively (Teng et al., 2013; Afolayan et al., 2016; Omura et al., 2016; Rana et al., 2020). EC-specific AMPK knockout mice (EC-AMPK ${ }^{-/-}$) (Omura et al., 2016) and EC-specific AMPK $\alpha 2$ knockout mice (EC-AMPK $\alpha 2^{-/-}$) (Zhang et al., 2018) have accelerated development of PH under conditions of hypoxia. Endothelial AMPK exerts protective effects against $\mathrm{PH}$ via, (1) paracrine growth mechanism (e.g., PDGF-BB and FGF-2) mediation of the interaction between pulmonary artery ECs and pulmonary VSMCs (Omura et al., 2016), (2) positive regulation of nitric oxide (NO) production via endothelial NO synthase (eNOS) phosphorylation (Zhang et al., 2006; Chen et al., 2009; Afolayan et al., 2016), (3) stabilization of angiotensin-converting enzyme 2 (ACE2) to increase angiotensin 1-7 (Ang 1-7) expression and eNOS-derived NO bioavailability (Zhang et al., 2006), (4) $\mathrm{Ca}^{2+}$ influx in pulmonary microvascular ECs, which promotes endothelial barrier function (Creighton et al., 2011), (5) notch ligand promotion of angiogenesis (200), and (6) alleviation of EC apoptosis (Ido et al., 2002; Nagata et al., 2009; Enkhjargal et al., 2014).

\section{AMPK in Vascular Smooth Muscle Cells and PH}

During $\mathrm{PH}$ development, the remodeling process universally involves medial thickening driven by VSMC proliferation/hypertrophy and deposition of extracellular matrix within the tunica media of pulmonary arteries (Lyle et al., 2017). Pulmonary VSMCs express both the AMPK $\alpha 1$ and AMPK $\alpha 2$ subunits of AMPK (Creighton et al., 2011; Ibe et al., 2013). However, AMPK $\alpha 1$ is the predominant subunit in pulmonary VSMCs and contributes up to $80 \%$ of total AMPK activity (Evans et al., 2005; Xue et al., 2017). AMPK $\alpha 1$ catalytic activity is much higher in VSMCs from small pulmonary arteries than in those from the main pulmonary arteries (Evans et al., 2005). Unlike AMPK in pulmonary ECs, studies of AMPK in pulmonary VSMCs have found contradictory results. Some studies found that phosphorylated AMPK is increased, while total AMPK levels remain the same, in pulmonary VSMCs from pulmonary hypertensive patients and hypoxia-induced $\mathrm{PH}$ mice, compared with those from healthy donors or non-PH mice, respectively (Krymskaya et al., 2011; Ibe et al., 2013). Mechanistically, hypoxia-activated AMPK promotes pulmonary VSMC survival, but AMPK activity pharmacologically inhibited by either compound $\mathrm{C}$ or $9-\beta$-d-arabinofuranosyl adenine (Araa) abrogates hypoxia-induced pulmonary VSMC proliferation and PH (Ibe et al., 2013; Xue et al., 2017). Ibe et al. (2013) found that although suppression of either AMPK $\alpha 1$ or $\alpha 2$ in pulmonary VSMCs leads to increased cell death, AMPK $\alpha 1$ and AMPK $\alpha 2$ have differential roles. Activation of AMPK $\alpha 1$ stimulates autophagy and promotes pulmonary VSMC survival; activation of AMPK $\alpha 2$ regulates myeloid cell leukemia sequence 1 (MCL-1) to prevent apoptosis (Ibe et al., 2013). In contrast to these results, another series of studies found that phosphorylated AMPK is decreased in pulmonary VSMCs from patients with $\mathrm{PH}$ and from mice with hypoxia-induced $\mathrm{PH}$, compared with those from healthy donors or non-PH mice, respectively (Goncharov et al., 2014). AMPK inhibition promotes pulmonary VSMC proliferation and survival, but AMPK pharmacologically activated by metformin or AICAR inhibits hypoxia-induced pulmonary VSMC proliferation and chronic $\mathrm{PH}$ (Agard et al., 2009; Goncharov et al., 2014; Wu et al., 2014; Ke et al., 2016; Song et al., 2016; Gui et al., 2017; Liu et al., 2019).

Seemingly contradictory results should be interpreted with caution. In the study that found elevated AMPK phosphorylation in $\mathrm{PH}$ and AMPK inhibition-attenuated 




PH (Krymskaya et al., 2011; Ibe et al., 2013), the researchers used pulmonary VSMCs isolated from large-diameter arteries located in a segment of pulmonary arteries just proximal to where lung entry occurs (diameter $\geq 0.8 \mathrm{~mm}$ ). In the study that found AMPK reduction in $\mathrm{PH}$ and $\mathrm{PH}$ mitigation by AMPK activation (Goncharov et al., 2014), pulmonary VSMCs isolated from small-diameter arteries located in distal pulmonary artery segments (type III, diameter $\leq 0.1 \mathrm{~mm}$ ) were used. Therefore, these discrepancies may be due to different functions of AMPK or different AMPK isoforms, or both, in pulmonary arteries with different diameters. Hypoxic pulmonary vasoconstriction is more vigorous in small pulmonary arteries (Dawson et al., 1977; Grimm et al., 1978; Sylvester et al., 2012), where the AMPK $\alpha 1$ catalytic subunit is predominantly expressed (Evans et al., 2005). The non-selective nature of AMPK activators or inhibitors may be another factor that contributes to these apparent inconsistencies.

\section{AMPK and Pulmonary Hypertension Treatment \\ AMPK Inhibition Is Preventive for Development of Pulmonary Hypertension}

Ibe et al. (2013) found that inhibition of AMPK by compound $\mathrm{C}$ prevents development of hypoxia-induced $\mathrm{PH}$. When mice treated with compound $\mathrm{C}$ one day before hypoxia exposure (10\% oxygen for 3 weeks), compound C prevents hypoxiainduced $\mathrm{PH}$, pulmonary arterial wall thickening, and right ventricular hypertrophy. The activation of AMPK $\alpha 1$ stimulates autophagy, promoting pulmonary VSMCs survival, whereas the activation of AMPK $\alpha 2$ increases the expression of myeloid cell leukemia sequence 1 (MCL-1), inhibiting pulmonary VSMCs apoptosis (Ibe et al., 2013). Consistent with these results, Robertson et al. (2008) and Evans et al. (2009) pre-incubated intrapulmonary arteries (3rd and 4th order branches of the pulmonary arterial tree, $0.2-0.5 \mathrm{~mm}$ internal diameter) with compound C (40 mM). Compound C reversed/inhibited hypoxic pulmonary vasoconstriction in a concentration-dependent manner. Functionally, AMPK phosphorylates voltage-gated $\mathrm{K}^{+}$channel (Kv2.1) and thereby confers a leftward shift in both the activation and inactivation curves of Kv2.1, which precipitates an increase in the intracellular $\mathrm{Ca}^{2+}$ concentration (Evans et al., 2009).

\section{AMPK Activation Is Preventive for Development of Pulmonary Hypertension}

A significant body of evidence suggests that AMPK activation is preventive for development of $\mathrm{PH}$. Metformin, the first-line medication for treatment of type 2 diabetes and the canonical 
TABLE 2 | Pulmonary hypertension (PH) animal experiments of AMPK.

\begin{tabular}{|c|c|c|c|c|c|c|}
\hline Therapy & Dose (mg/kg/day) & Route & Time (day) & PH models & Sex & References \\
\hline \multicolumn{7}{|c|}{ AMPK activator with beneficial effects on $\mathrm{PH}$} \\
\hline Metformin & $100-150$ & p.o. & $21-28$ & MCT rat & $\mathrm{M}$ & Zhai et al., 2018; Yoshida et al., 2020 \\
\hline Metformin & $100-150$ & i.p. & $21-28$ & MCT rat & M & Agard et al., 2009; Li et al., 2016 \\
\hline Metformin & 100 & i.p. & 30 & MCT rat & & Sun et al., 2019 \\
\hline Metformin & 100 & i.p. & 21 & Hypoxia rat & & Liu et al., 2019 \\
\hline Metformin & 100 & p.o. & 21 & $\mathrm{Su} / \mathrm{H} \times$ rat & $\mathrm{F}$ & Dean et al., 2016 \\
\hline Metformin & 300 & p.o. & $31-28$ & Obese ZSF1 rat & $\mathrm{M}$ & Lai et al., 2016 \\
\hline Metformin & 300 & p.o. & 98 & SU5416/Obese ZSF1 rat & $\mathrm{F}$ & Wang et al., 2020 \\
\hline Metformin & 150 & i.p. & 14 & $\mathrm{Su} / \mathrm{H} \times$ mouse & M & Zhang et al., 2018 \\
\hline Metformin & 100 & p.o. & 21 & Hypoxia mouse & M & Omura et al., 2016 \\
\hline AICAR & $1 ?$ & i.p. & 28 & Hypoxia rat & M & Huang et al., 2014; Chen et al., 2016 \\
\hline \multicolumn{7}{|c|}{ AMPK antagonist with beneficial effects on $\mathrm{PH}$} \\
\hline Compound C & 20 & i.p. & 21 & Hypoxia mouse & M & Ibe et al., 2013 \\
\hline \multicolumn{7}{|c|}{ AMPK activators without effects on $\mathrm{PH}$} \\
\hline Metformin & 100 & p.o. & 14 & SuHx mouse & $M$ & Goncharov et al., 2018 \\
\hline Metformin & 300 & p.o. & 42 & SuHx rat & M & Goncharov et al., 2018 \\
\hline AICAR & 500 & p.o. & 42 & SuHx rat & M & Goncharov et al., 2018 \\
\hline
\end{tabular}

p.o., oral administration (per os); i.p., Intraperitoneal injection.

AMPK activator, demonstrates therapeutic efficacy on $\mathrm{PH}$ in animal models. AMPK activation by metformin prevents MCTinduced PH in rats (Agard et al., 2009; Li et al., 2016; Zhai et al., 2018; Sun et al., 2019; Yoshida et al., 2020). In these experimental models, rats were injected with one dose of MCT $(60 \mathrm{mg} / \mathrm{kg})$ to induce PH. Metformin (100-150 mg/kg/day, drinking water or intraperitoneal injection, 21-30 days) treatment significantly reduced right ventricular systolic pressure and pulmonary vascular remodeling in rats with MCT-induced PH (Agard et al., 2009; Li et al., 2016; Zhai et al., 2018; Sun et al., 2019; Yoshida et al., 2020). Consistent with these results, metformin has protective effects on hypoxia-induced $\mathrm{PH}$ in mice and rats (Huang et al., 2014; Omura et al., 2016; Liu et al., 2019), and a more pronounced $\mathrm{PH}$ with angioobliterative lesions in Sugen 5416/hypoxia (SuHx) mice/rats (Dean et al., 2016; Zhang et al., 2018) and SU5416/Obese ZSF1 rats (Lai et al., 2016; Wang et al., 2020). The AMPK activator, AICAR, also prevents $\mathrm{PH}$ development in rats with hypoxia-induced $\mathrm{PH}$ (Huang et al., 2014; Chen et al., 2016).

In contrast to the results that metformin has protective effects, other researchers reported that their findings did not support the efficacy of metformin in PAH therapy (Goncharov et al., 2018). Goncharov et al. (2018) findings suggested that metformin treatment may be preferentially beneficial for $\mathrm{PH}$ with heart failure with preserved ejection fraction ( $\mathrm{PH}-\mathrm{HFpEF}$, group $2 \mathrm{PH}$ ), but that it has limited efficacy for $\mathrm{PAH}$. They induced $\mathrm{PAH}$ in a male C57BL/6J mouse model using a 3-week exposure to SuHx. They then gave metformin (100 mg/kg/day, 14 days) in drinking water for 2 -weeks post hypoxia exposure. Goncharov et al. found no changes in right ventricular systolic pressure, right ventricular hypertrophy, or pulmonary vascular remodeling in the metformin-treated SuHx mice. They also evaluated the preventive effects of metformin and AICAR in PAH. In these animal models, metformin $(300 \mathrm{mg} / \mathrm{kg} / \mathrm{day}$, drinking water,
42 days) or AICAR (500 mg/kg/day, intraperitoneal, 42 days) were administrated 1 day before SuHx exposure. They found no changes in right ventricular systolic pressure, right ventricular hypertrophy, or pulmonary vascular remodeling in either the metformin- or AICAR-treated SuHx rats. However, they did not measure phosphorylation levels of AMPK or downstream AMPK pathways. Metformin-induced AMPK activation requires full activation of an upstream kinase (e.g., LKB1), especially at low doses (Choi et al., 2001; Emerling et al., 2009; Zmijewski et al., 2010; Hinchy et al., 2018). Therefore, it is unknown whether the lack of metformin efficacy for $\mathrm{PH}$ treatment was associated with AMPK activation.

Different characteristics that likely contribute to apparently contradictory results are presented in Table 2 . In Dean et al. (2016), AMPK activation by metformin (100 mg/kg/day, oral gavage, 21 days) seems to reverse the $\mathrm{PH}$ phenotype induced by SuHx in female rats, in contrast to the findings of Goncharov et al. (2018) that was performed using male rats. Thus, a sex difference might affect the response to metformin treatment of PH. Effects of this difference have been described for other diseases (e.g., obesity, aging, and spontaneous tumorigenesis) (Anisimov et al., 2010; Quan et al., 2016; Park et al., 2017; Bramante et al., 2021).

\section{Clinical Trials of Pulmonary Hypertension Treatment Using Metformin}

There has been significant interest in the use of metformin for PH treatment. Liao et al. $(2018,2019)$ found that a combination therapy using metformin (500 mg, twice daily, 3 months) and bosentan (endothelin receptor antagonist) improves 6-min walk distance and right heart hemodynamics, decreases serum pro-brain natriuretic peptide (pro-BNP) levels, and ameliorates pulmonary vasoconstriction in patients with $\mathrm{PH}$ associated with congenital heart defects. Two phase I/II clinical trials of 
metformin for $\mathrm{PH}$ treatment are in progress (clinicaltrials.gov, NCT01884051 and NCT03629340). Results to date indicate good tolerability and potential clinical efficacy for improvement in right ventricular function in patients with $\mathrm{PH}$ who receive metformin therapy (2 g/day, 8 weeks) (Brittain et al., 2020). However, metformin use did not change the 6-min walk distance in those patients (Brittain et al., 2020). Although not yet complete, this clinical study provides new insights into the potential benefits of metformin use on right ventricular failure in patients with $\mathrm{PH}$ and indicates the need for more studies of the use of metformin therapeutic intervention in patients with $\mathrm{PH}$ and $\mathrm{PH}-\mathrm{HFpEF}$.

\section{CONCLUSION AND PERSPECTIVES}

In this review, we discussed some seemingly contradictory study results for AMPK and PH development. AMPK has a key role in $\mathrm{PH}$, either during the early process of hypoxic pulmonary vasoconstriction or later during pulmonary vasculature remodeling, or both. However, whether AMPK activation or inhibition is protective against $\mathrm{PH}$ remains unclear: (1) AMPK activation triggers hypoxia-induced pulmonary artery constriction. AMPK activator use (e.g., AICAR and Ara-a) prevents hypoxia-induced pulmonary artery constriction and PH. (2) EC-specific deletion of AMPK exaggerates hypoxiainduced $\mathrm{PH}$ in vivo. This result indicates endothelial AMPK has a protective role during PH development. (3) VSMCs from large pulmonary arteries with AMPK activation have accelerated proliferation and inhibited apoptosis. VSMCs from distal small pulmonary arteries with AMPK inhibition have similar potential. (4) Some animal studies found that the AMPK activators, AICAR and metformin, have beneficial effects on $\mathrm{PH}$ treatment. Other study findings suggest that metformin therapy for $\mathrm{PH}$ may be limited to use for PH-HFpEF. AMPK activation might have less pronounced pulmonary vascular effects than right ventricular effects, as much evidence has been published suggesting that

\section{REFERENCES}

Afolayan, A. J., Eis, A., Alexander, M., Michalkiewicz, T., Teng, R.-J., Lakshminrusimha, S., et al. (2016). Decreased endothelial nitric oxide synthase expression and function contribute to impaired mitochondrial biogenesis and oxidative stress in fetal lambs with persistent pulmonary hypertension. Am. J. Physiol. Lung Cell. Mol. Physiol. 310, L40-L49.

Agard, C., Rolli-Derkinderen, M., Dumas-de-La-Roque, E., Rio, M., Sagan, C., Savineau, J. P., et al. (2009). Protective role of the antidiabetic drug metformin against chronic experimental pulmonary hypertension. Br. J. Pharmacol. 158, 1285-1294. doi: 10.1111/j.1476-5381.2009.00445.x

Ahmad, F., Arad, M., Musi, N., He, H., Wolf, C., Branco, D., et al. (2005). Increased alpha2 subunit-associated AMPK activity and PRKAG2 cardiomyopathy. Circulation 112, 3140-3148. doi: 10.1161/circulationaha.105.550806

Anisimov, V. N., Piskunova, T. S., Popovich, I. G., Zabezhinski, M. A., Tyndyk, M. L., Egormin, P. A., et al. (2010). Gender differences in metformin effect on aging, life span and spontaneous tumorigenesis in 129/Sv mice. Aging (Albany N. Y.) 2, 945-958. doi: 10.18632/aging.10 0245

Arad, M., Seidman, C. E., and Seidman, J. G. (2007). AMP-activated protein kinase in the heart. Circulat. Res. 100, 474-488.
AMPK activation exerts a protective effect in cardiac dysfunction, ischemic heart, heat failure, and cardiac hypertrophy (Russell et al., 2004; Miller et al., 2008; Ma et al., 2010; Kim et al., 2011; Morrison et al., 2011). (5) Sex differences in the response to metformin used for PH treatment may affect outcomes.

In conclusion, studies found seemingly contradictory results for the relationship between AMPK and PH. In one series of studies, inhibition of AMPK resulted in attenuated hypoxic pulmonary vasoconstriction and pulmonary VSMC proliferation. In another series of studies, activation of AMPK resulted in improved EC function, VSMC apoptosis, and decreased pulmonary vasculature tone. Given that AMPK al and AMPK a2 have different expression patterns and different functions in pulmonary arteries of different sizes, the role of AMPK in PH should be studied using a cell-specific and pathological processspecific approach. Studies involving genetically- and specificallymodified AMPK $\alpha 1$ and $\alpha 2$ subunits are needed to clarify their specific roles in $\mathrm{PH}$ pathogenesis and treatment.

\section{AUTHOR CONTRIBUTIONS}

QZ drafted the manuscript and figures. PS and M-HZ revised the manuscript. All authors contributed to the article and approved the submitted version.

\section{FUNDING}

This work was supported in part by National Heart, Lung, and Blood Institute (HL079584, HL080499, HL089920, HL110488, HL128014, HL132500, HL137371, and HL142287), National Cancer Institute (CA213022), and National Institute on Aging (AG047776) (to M-HZ) and HL140954 (PS). QZ is a recipient of Postdoctoral Fellowship Award of American Heart Association (835456).

Archer, S., and Michelakis, E. (2002). The mechanism(s) of hypoxic pulmonary vasoconstriction: potassium channels redox $\mathrm{O} 2$ sensors, and controversies. Physiology 17, 131-137. doi: 10.1152/nips.01388.2002

Attinà, T., Camidge, R., Newby, D. E., and Webb, D. J. (2005). Endothelin antagonism in pulmonary hypertension, heart failure, and beyond. Heart 91, 825-831. doi: 10.1136/hrt.2004.053991

Bando, H., Atsumi, T., Nishio, T., Niwa, H., Mishima, S., Shimizu, C., et al. (2005). Phosphorylation of the 6-phosphofructo-2-kinase/fructose 2,6-bisphosphatase/PFKFB3 family of glycolytic regulators in human cancer. Clin. Cancer Res. 11, 5784-5792. doi: 10.1158/1078-0432.ccr-050149

Bergeron, R., Ren, J. M., Cadman, K. S., Moore, I. K., Perret, P., Pypaert, M., et al. (2001). Chronic activation of AMP kinase results in NRF-1 activation and mitochondrial biogenesis. Am. J. Physiol. Endocrinol. Metabol. 281, E1340E1346.

Bergofsky, E. H., Holtzman, S., and Study, A. (1967). A study of the mechanisms involved in the pulmonary arterial pressor response to hypoxia. Circulat. Res. 20, 506-519. doi: 10.1161/01.res.20.5.506

Bigham, A. W., Julian, C. G., Wilson, M. J., Vargas, E., Browne, V. A., Shriver, M. D., et al. (2014). Maternal PRKAA1 and EDNRA genotypes are associated with birth weight, and PRKAA1 with uterine artery diameter and metabolic 
homeostasis at high altitude. Physiol. Genom. 46, 687-697. doi: 10.1152/ physiolgenomics.00063.2014

Bradford, J. R., and Dean, H. P. (1894). The pulmonary circulation. J. Physiol. 16, 34-158.25.

Bramante, C. T., Ingraham, N. E., Murray, T. A., Marmor, S., Hovertsen, S., Gronski, J., et al. (2021). Metformin and risk of mortality in patients hospitalised with COVID-19: a retrospective cohort analysis. Lancet Health. Longev. 2, e34-e41.

Brittain, E. L., Niswender, K., Agrawal, V., Chen, X., Fan, R., Pugh, M. E., et al. (2020). Mechanistic phase II clinical trial of metformin in pulmonary arterial hypertension. J. Am. Heart Associat. 9:e018349.

Brown-Séquard, C. E. (1871). On the production of hæmorrhage, anæmia, śdema, and emphysema in the lungs by injuries to the base of the brain. Lancet 97:6. doi: 10.1016/s0140-6736(02)77750-7

Budhiraja, R., Tuder, R. M., and Hassoun, P. M. (2004). Endothelial dysfunction in pulmonary hypertension. Circulation 109, 159-165.

Bungard, D., Fuerth, B. J., Zeng, P.-Y., Faubert, B., Maas, N. L., Viollet, B., et al. (2010). Signaling kinase AMPK activates stress-promoted transcription via histone H2B phosphorylation. Science 329, 1201-1205. doi: 10.1126/science. 1191241

Carling, D., Zammit, V. A., and Hardie, D. G. (1987). A common bicyclic protein kinase cascade inactivates the regulatory enzymes of fatty acid and cholesterol biosynthesis. FEBS Lett. 223, 217-222. doi: 10.1016/0014-5793(87)80292-2

Chandra, S. M., Razavi, H., Kim, J., Agrawal, R., Kundu, R. K., de Jesus Perez, V., et al. (2011). Disruption of the apelin-APJ system worsens hypoxia-induced pulmonary hypertension. Arterioscler. Thrombos. Vascul. Biol. 31, 814-820. doi: 10.1161/atvbaha.110.219980

Chen, L., Xin, F.-J., Wang, J., Hu, J., Zhang, Y.-Y., Wan, S., et al. (2013). Conserved regulatory elements in AMPK. Nature 498, E8-E10.

Chen, M., Cai, H., Yu, C., Wu, P., Fu, Y., Xu, X., et al. (2016). Salidroside exerts protective effects against chronic hypoxia-induced pulmonary arterial hypertension via AMPK $\alpha 1$-dependent pathways. Am. J. Transl. Res. 8, 12-27.

Chen, Z., Peng, I. C., Sun, W., Su, M. I., Hsu, P. H., Fu, Y., et al. (2009). AMP-activated protein kinase functionally phosphorylates endothelial nitric oxide synthase Ser633. Circulat. Res. 104, 496-505. doi: 10.1161/circresaha.108. 187567

Cheung, P. C., Salt, I. P., Davies, S. P., Hardie, D. G., and Carling, D. (2000). Characterization of AMP-activated protein kinase gamma-subunit isoforms and their role in AMP binding. Biochem. J. 346(Pt 3), 659-669. doi: 10.1042/ 0264-6021:3460659

Choi, S.-L., Kim, S.-J., Lee, K.-T., Kim, J., Mu, J., Birnbaum, M. J., et al. (2001). The regulation of AMP-activated protein kinase by $\mathrm{H} 2 \mathrm{O} 2$. Biochem. Biophys. Res. Commun. 287, 92-97.

Colvin, K. L., and Yeager, M. E. (2014). Animal models of pulmonary hypertension: matching disease mechanisms to etiology of the human disease. J. Pulmon. Respirat. Med. 4:198.

Creighton, J., Jian, M., Sayner, S., Alexeyev, M., and Insel, P. A. (2011). Adenosine monophosphate-activated kinase alphal promotes endothelial barrier repair. FASEB J. 25, 3356-3365. doi: 10.1096/fj.10-179218

Davies, S. P., Helps, N. R., Cohen, P. T. W., and Hardie, D. G. (1995). 5'-AMP inhibits dephosphorylation, as well as promoting phosphorylation, of the AMPactivated protein kinase. Studies using bacterially expressed human protein phosphatase-2C $\alpha$ and native bovine protein phosphatase-2Ac. FEBS Lett. 377, 421-425. doi: 10.1016/0014-5793(95)01368-7

Dawson, C. A., Grimm, D. J., and Linehan, J. H. (1977). Effects of lung inflation on longitudinal distribution of pulmonary vascular resistance. J. Appl. Physiol. 43, 1089-1092. doi: 10.1152/jappl.1977.43.6.1089

Day, E. A., Ford, R. J., and Steinberg, G. R. (2017). AMPK as a therapeutic target for treating metabolic diseases. Trends Endocrinol. Metabol. 28, 545-560. doi: 10.1016/j.tem.2017.05.004

de Theije, C. C., Schols, A., Lamers, W. H., Neumann, D., Köhler, S. E., and Langen, R. C. J. (2018). Hypoxia impairs adaptation of skeletal muscle protein turnover- and AMPK signaling during fasting-induced muscle atrophy. PLoS One 13:e0203630. doi: 10.1371/journal.pone.0203630

Dean, A., Nilsen, M., Loughlin, L., Salt, I. P., and MacLean, M. R. (2016). Metformin reverses development of pulmonary hypertension via aromatase inhibition. Hypertension 68, 446-454. doi: 10.1161/hypertensionaha.116. 07353
Dengler, F., and Gäbel, G. (2019). The fast lane of hypoxic adaptation: glucose transport is modulated via a HIF-hydroxylase-AMPK-axis in jejunum epithelium. Int. J. Mol. Sci. 20:4993. doi: 10.3390/ijms20204993

Detar, R. (1980). Mechanism of physiological hypoxia-induced depression of vascular smooth muscle contraction. Am. J. Physiol. 238, H761-H769.

Ducommun, S., Deak, M., Sumpton, D., Ford, R. J., úñez Galindo, A. N., Kussmann, M., et al. (2015). affinity and mass spectrometry proteomic approach for the discovery of cellular AMPK targets: identification of mitochondrial fission factor as a new AMPK substrate. Cell. Signal. 27, 978-988. doi: 10.1016/ j.cellsig.2015.02.008

Dumitrascu, R., Koebrich, S., Dony, E., Weissmann, N., Savai, R., Pullamsetti, S. S., et al. (2008). Characterization of a murine model of monocrotaline pyrrole-induced acute lung injury. BMC Pulmon. Med. 8:25.

Dummer, A., Rol, N., Szulcek, R., Kurakula, K., Pan, X., Visser, B. I., et al. (2018) Endothelial dysfunction in pulmonary arterial hypertension: loss of cilia length regulation upon cytokine stimulation. Pulmon. Circulat. 8:2045894018764629.

Dunham-Snary, K. J., Wu, D., Sykes, E. A., Thakrar, A., Parlow, L. R. G., Mewburn, J. D., et al. (2017). Hypoxic pulmonary vasoconstriction: from molecular mechanisms to medicine. Chest 151, 181-192.

Egan, D. F., Shackelford, D. B., Mihaylova, M. M., Gelino, S., Kohnz, R. A., Mair, W., et al. (2011). of ULK1 (hATG1) by AMP-activated protein kinase connects energy sensing to mitophagy. Science 331, 456-461. doi: 10.1126/ science. 1196371

Emerling, B. M., Weinberg, F., Snyder, C., Burgess, Z., Mutlu, G. M., Viollet, B., et al. (2009). Hypoxic activation of AMPK is dependent on mitochondrial ROS but independent of an increase in AMP/ATP ratio. Free Rad. Biol. Med. 46, 1386-1391. doi: 10.1016/j.freeradbiomed.2009.02.019

Emilio, P., Mottillo, E. M., Desjardins, J. D., Crane, B. K., Smith, A. E., Green, S. D., et al. (2016). Lack of adipocyte AMPK exacerbates insulin resistance and hepatic steatosis through brown and beige adipose tissue function. Cell Metab. 24, 118-129. doi: 10.1016/j.cmet.2016.06.006

Enkhjargal, B., Godo, S., Sawada, A., Suvd, N., Saito, H., Noda, K., et al. (2014). Endothelial AMP-activated protein kinase regulates blood pressure and coronary flow responses through hyperpolarization mechanism in mice. Arterioscl. Thromb. Vascul. Biol. 34, 1505-1513. doi: 10.1161/atvbaha.114. 303735

Evans, A. M. (2006). AMP-activated protein kinase underpins hypoxic pulmonary vasoconstriction and carotid body excitation by hypoxia in mammals. Exp. Physiol. 91, 821-827. doi: 10.1113/expphysiol.2006.033514

Evans, A. M., Hardie, D. G., Peers, C., Wyatt, C. N., Viollet, B., Kumar, P., et al. (2009). Ion channel regulation by AMPK. Annal. N. Y. Acad. Sci. 1177, 89-100.

Evans, A. M., Mustard, K. J., Wyatt, C. N., Dipp, M., Kinnear, N. P., and Hardie, D. G. (2006). Does AMP-activated protein kinase couple inhibition of mitochondrial oxidative phosphorylation by hypoxia to pulmonary artery constriction? Adv. Exp. Med. Biol. 580, 147-154; discussion 351-9.

Evans, A. M., Mustard, K. J., Wyatt, C. N., Peers, C., Dipp, M., Kumar, P., et al. (2005). Does AMP-activated protein kinase couple inhibition of mitochondrial oxidative phosphorylation by hypoxia to calcium signaling in $\mathrm{O}_{2}$-sensing cells? J. Biol. Chem. 280, 41504-41511. doi: 10.1074/jbc.m510040200

Fogarty, S., and Hardie, D. G. (2010). Development of protein kinase activators: AMPK as a target in metabolic disorders and cancer. Biochim. Biophys. Acta (BBA) Prot. Proteom. 1804, 581-591. doi: 10.1016/j.bbapap.2009.09.012

Fullerton, M. D., Galic, S., Marcinko, K., Sikkema, S., Pulinilkunnil, T., Chen, Z.P., et al. (2013). Single phosphorylation sites in Acc1 and Acc2 regulate lipid homeostasis and the insulin-sensitizing effects of metformin. Nat. Med. 19, 1649-1654. doi: 10.1038/nm.3372

Galic, S., Fullerton, M. D., Schertzer, J. D., Sikkema, S., Marcinko, K., Walkley, C. R., et al. (2011). Hematopoietic AMPK $\beta 1$ reduces mouse adipose tissue macrophage inflammation and insulin resistance in obesity. J. Clin. Investigat. 121, 4903-4915. doi: 10.1172/jci58577

Galiè, N., and Simonneau, G. (2013). The fifth world symposium on pulmonary hypertension. J. Am. Coll. Cardiol. 62, D1-D3.

Galiè, N., Hoeper, M. M., Humbert, M., Torbicki, A., Vachiery, J. L., Barbera, J. A., et al. (2009). Guidelines for the diagnosis and treatment of pulmonary hypertension. Eur. Respirat. J. 34, 12191263.

Garcia-Roves, P. M., Osler, M. E., Holmström, M. H., and Zierath, J. R. (2008). Gain-of-function R225Q mutation in AMP-activated protein Kinase $\gamma 3$ subunit 
increases mitochondrial biogenesis in glycolytic skeletal muscle. J. Biol. Chem. 283, 35724-35734. doi: 10.1074/jbc.m805078200

Gomez-Arroyo, J. G., Farkas, L., Alhussaini, A. A., Farkas, D., Kraskauskas, D., Voelkel, N. F., et al. (2012). The monocrotaline model of pulmonary hypertension in perspective. Am. J. Physiol. Lung Cell. Mol. Physiol. 302, L363-L369.

Goncharov, D. A., Goncharova, E. A., Tofovic, S. P., Hu, J., Baust, J. J., Pena, A. Z., et al. (2018). Metformin therapy for pulmonary hypertension associated with heart failure with preserved ejection fraction versus pulmonary arterial hypertension. Am. J. Respirat. Crit. Care Med. 198, 681-684.

Goncharov, D. A., Kudryashova, T. V., Ziai, H., Ihida-Stansbury, K., DeLisser, H., Krymskaya, V. P., et al. (2014). Mammalian target of rapamycin complex 2 (mTORC2) coordinates pulmonary artery smooth muscle cell metabolism, proliferation, and survival in pulmonary arterial hypertension. Circulation 129, 864-874. doi: 10.1161/circulationaha.113.004581

Gowans, G. J., Hawley, S. A., Ross, F. A., and Hardie, D. G. (2013). AMP is a true physiological regulator of AMP-activated protein kinase by both allosteric activation and enhancing net phosphorylation. Cell Metab. 18, 556-566. doi: 10.1016/j.cmet.2013.08.019

Grimm, D. J., Dawson, C. A., Hakim, T. S., and Linehan, J. H. (1978). Pulmonary vasomotion and the distribution of vascular resistance in a dog lung lobe. J. Appl. Physiol. 45, 545-550. doi: 10.1152/jappl.1978.45.4.545

Gui, D., Cui, Z., Zhang, L., Yu, C., Yao, D., Xu, M., et al. (2017). Salidroside attenuates hypoxia-induced pulmonary arterial smooth muscle cell proliferation and apoptosis resistance by upregulating autophagy through the AMPK-mTOR-ULK1 pathway. BMC Pulmon. Med. 17:191.

Gwinn, D. M., Shackelford, D. B., Egan, D. F., Mihaylova, M. M., Mery, A., Vasquez, D. S., et al. (2008). AMPK phosphorylation of raptor mediates a metabolic checkpoint. Mol. Cell 30, 214-226. doi: 10.1016/j.molcel.2008.03.003

Hansmann, G., Wagner, R. A., Schellong, S., Perez, V. A. d. J., Urashima, T., Wang, L., et al. (2007). Pulmonary arterial hypertension is linked to insulin resistance and reversed by peroxisome proliferator-activated receptor-gamma activation. Circulation 115, 1275-1284. doi: 10.1161/circulationaha.106.663120

Hardie, D. G. (2008). AMPK: a key regulator of energy balance in the single cell and the whole organism. Int. J. Obes. 32, S7-S12.

Hardie, D. G. (2013). AMPK: a target for drugs and natural products with effects on both diabetes and cancer. Diabetes 62, 2164-2172. doi: $10.2337 / \mathrm{db}$ 13-0368

Hardie, D. G., Carling, D., and Gamblin, S. J. (2011). AMP-activated protein kinase: also regulated by ADP? Trends Biochem. Sci. 36, 470-477. doi: 10.1016/j.tibs. 2011.06.004

Hawley, S. A., Boudeau, J., Reid, J. L., Mustard, K. J., Udd, L., Mäkelä, T. P., et al. (2003). Complexes between the LKB1 tumor suppressor, STRAD alpha/beta and MO25 alpha/beta are upstream kinases in the AMP-activated protein kinase cascade. J. Biol. 2:28.

Hawley, S. A., Pan, D. A., Mustard, K. J., Ross, L., Bain, J., Edelman, A. M., et al. (2005). Calmodulin-dependent protein kinase kinase- $\beta$ is an alternative upstream kinase for AMP-activated protein kinase. Cell Metab. 2, 9-19. doi: 10.1016/j.cmet.2005.05.009

Heath, D., and Edwards, J. E. (1958). The pathology of hypertensive pulmonary vascular disease. Circulation 18, 533-547.

Herzig, S., and Shaw, R. J. (2018). AMPK: guardian of metabolism and mitochondrial homeostasis. Nat. Rev. Mol. Cell Biol. 19, 121-135. doi: 10.1038/ nrm.2017.95

Hinchy, E. C., Gruszczyk, A. V., Willows, R., Navaratnam, N., Hall, A. R., Bates, G., et al. (2018). Mitochondria-derived ROS activate AMP-activated protein kinase (AMPK) indirectly. J. Biol. Chem. 293, 17208-17217. doi: 10.1074/jbc.ra118. 002579

Hoeper, M. M., Lam, C. S. P., Vachiery, J.-L., Bauersachs, J., Gerges, C., Lang, I. M., et al. (2016). Pulmonary hypertension in heart failure with preserved ejection fraction: a plea for proper phenotyping and further research. Eur. Heart J. 38, 2869-2873.

Hong, S.-P., Momcilovic, M., and Carlson, M. (2005). Function of mammalian LKB1 and Ca2+/calmodulin-dependent protein kinase kinase $\alpha$ as Snf1activating kinases in yeast. J. Biol. Chem. 280, 21804-21809. doi: 10.1074/jbc. m501887200

Huang, X., Fan, R., Lu, Y., Yu, C., Xu, X., Zhang, X., et al. (2014). Regulatory effect of AMP-activated protein kinase on pulmonary hypertension induced by chronic hypoxia in rats: in vivo and in vitro studies. Mol. Biol. Rep. 41, 4031-4041. doi: 10.1007/s11033-014-3272-9

Hudson, E. R., Pan, D. A., James, J., Lucocq, J. M., Hawley, S. A., Green, K. A., et al. (2003). A novel domain in AMP-activated protein kinase causes glycogen storage bodies similar to those seen in hereditary cardiac arrhythmias. Curr. Biol. 13, 861-866. doi: 10.1016/s0960-9822(03)00249-5

Humbert, M., Guignabert, C., Bonnet, S., Dorfmüller, P., Klinger, J. R., Nicolls, M. R., et al. (2019). Pathology and pathobiology of pulmonary hypertension: state of the art and research perspectives. Eur. Respirat. J. 53:1801887. doi: 10.1183/13993003.01887-2018

Hurley, R. L., Anderson, K. A., Franzone, J. M., Kemp, B. E., Means, A. R., and Witters, L. A. (2005). The Ca2+/calmodulin-dependent protein kinase kinases are AMP-activated protein kinase kinases. J. Biol. Chem. 280, 29060-29066. doi: 10.1074/jbc.m503824200

Ibe, J. C. F., Zhou, Q., Chen, T., Tang, H., Yuan, J. X. J., Raj, J. U., et al. (2013). Adenosine monophosphate-activated protein kinase is required for pulmonary artery smooth muscle cell survival and the development of hypoxic pulmonary hypertension. Am. J. Respirat. Cell Mol. Biol. 49, 609-618. doi: 10.1165/rcmb. 2012-0446oc

Ido, Y., Carling, D., and Ruderman, N. (2002). Hyperglycemia-induced apoptosis in human umbilical vein endothelial cells: inhibition by the AMP-activated protein kinase activation. Diabetes 51, 159-167. doi: 10.2337/diabetes.51.1.159

Inoki, K., Zhu, T., and Guan, K.-L. (2003). TSC2 mediates cellular energy response to control cell growth and survival. Cell 115, 577-590. doi: 10.1016/s00928674(03)00929-2

Jasmin, J. F., Lucas, M., Cernacek, P., and Dupuis, J. (2001). Effectiveness of a nonselective $\mathrm{ET}(\mathrm{A} / \mathrm{B})$ and a selective $\mathrm{ET}(\mathrm{A})$ antagonist in rats with monocrotaline-induced pulmonary hypertension. Circulation 103, 314-318. doi: 10.1161/01.cir.103.2.314

Kahn, B. B., Alquier, T., Carling, D., and Hardie, D. G. (2005). AMP-activated protein kinase: Ancient energy gauge provides clues to modern understanding of metabolism. Cell Metab. 1, 15-25. doi: 10.1016/j.cmet.2004.12.003

Kay, J. M., Harris, P., and Heath, D. (1967). Pulmonary hypertension produced in rats by ingestion of Crotalaria spectabilis seeds. Thorax 22, 176-179. doi: 10.1136/thx.22.2.176

Ke, R., Liu, L., Zhu, Y., Li, S., Xie, X., Li, F., et al. (2016). Knockdown of $\mathrm{AMPK} \alpha 2$ promotes pulmonary arterial smooth muscle cells proliferation via mTOR/Skp2/p27(Kip1) signaling pathway. Int. J. Mol. Sci. 17:844. doi: 10.3390/ ijms17060844

Kelly, M., Keller, C., Avilucea, P. R., Keller, P., Luo, Z., Xiang, X., et al. (2004). AMPK activity is diminished in tissues of IL- 6 knockout mice: the effect of exercise. Biochem. Biophys. Res. Commun. 320, 449-454. doi: 10.1016/j.bbrc. 2004.05.188

Kemp, B. E. (2004). Bateman domains and adenosine derivatives form a binding contract. J. Clin. Investigat. 113, 182-184. doi: 10.1172/jci200420846

Kim, A. S., Miller, E. J., Wright, T. M., Li, J., Qi, D., Atsina, K., et al. (2011). A small molecule AMPK activator protects the heart against ischemia-reperfusion injury. J. Mol. Cell. Cardiol. 51, 24-32. doi: 10.1016/j.yjmcc.2011.03.003

Kim, E. K., Lee, J. H., Oh, Y. M., Lee, Y. S., and Lee, S. D. (2010). Rosiglitazone attenuates hypoxia-induced pulmonary arterial hypertension in rats. Respirology (Carlton Vic.) 15, 659-668. doi: 10.1111/j.1440-1843.2010. 01756.x

Kim, J. (2014). Apelin-APJ signaling: a potential therapeutic target for pulmonary arterial hypertension. Mol. Cell. 37, 196-201. doi: 10.14348/molcells.20 14.2308

Kim, J., Yang, G., Kim, Y., Kim, J., and Ha, J. (2016). AMPK activators: mechanisms of action and physiological activities. Exp. Mol. Med. 48:e224. doi: 10.1038/ emm.2016.16

Klinger, J. R., Abman, S. H., and Gladwin, M. T. (2013). Nitric oxide deficiency and endothelial dysfunction in pulmonary arterial hypertension. Am. J. Respirat. Crit. Care Med. 188, 639-646. doi: 10.1164/rccm.2013040686pp

Kola, B. (2008). Role of AMP-activated protein kinase in the control of appetite. J. Neuroendocrinol. 20, 942-951. doi: 10.1111/j.1365-2826.2008.01745.x

Kola, B., Hubina, E., Tucci, S. A., Kirkham, T. C., Garcia, E. A., Mitchell, S. E., et al. (2005). Cannabinoids and ghrelin have both central and peripheral metabolic and cardiac effects via AMP-activated protein kinase. J. Biol. Chem. 280, 25196-25201. doi: 10.1074/jbc.c500175200 
Koo, S.-H., Flechner, L., Qi, L., Zhang, X., Screaton, R. A., Jeffries, S., et al. (2005). The CREB coactivator TORC2 is a key regulator of fasting glucose metabolism. Nature 437, 1109-1114. doi: 10.1038/nature03967

Krymskaya, V. P., Snow, J., Cesarone, G., Khavin, I., Goncharov, D. A., Lim, P. N., et al. (2011). mTOR is required for pulmonary arterial vascular smooth muscle cell proliferation under chronic hypoxia. FASEB J. 25, 1922-1933. doi: 10.1096/fj.10-175018

Lai, Y. C., Tabima, D. M., Dube, J. J., Hughan, K. S., Vanderpool, R. R., Goncharov, D. A., et al. (2016). ESIRT3-AMP-activated protein kinase activation by nitrite and metformin improves hyperglycemia and normalizes pulmonary hypertension associated with heart failure with preserved ejection fraction. Circulation 133, 717-731. doi: 10.1161/circulationaha.115.018935

Lamia, K. A., Sachdeva, U. M., DiTacchio, L., Williams, E. C., Alvarez, J. G., Egan, D. F., et al. (2009). AMPK regulates the circadian clock by cryptochrome phosphorylation and degradation. Science 326, 437-440. doi: 10.1126/science. 1172156

Legchenko, E., Chouvarine, P., Borchert, P., Fernandez-Gonzalez, A., Snay, E., Meier, M., et al. (2018). PPAR $\gamma$ agonist pioglitazone reverses pulmonary hypertension and prevents right heart failure via fatty acid oxidation. Sci. Transl. Med. 10:0303.

Li, M., Riddle, S. R., Frid, M. G., El Kasmi, K. C., McKinsey, T. A., Sokol, R. J., et al. (2011). Emergence of fibroblasts with a proinflammatory epigenetically altered phenotype in severe hypoxic pulmonary hypertension. J. Immunol. 187, 2711-2722. doi: 10.4049/jimmunol.1100479

Li, S., Han, D., Zhang, Y., Xie, X., Ke, R., Zhu, Y., et al. (2016). Activation of AMPK prevents monocrotaline-induced extracellular matrix remodeling of pulmonary artery. Med. Sci. Monit. Basic Res. 22, 27-33. doi: 10.12659/msmbr.897505

Li, Y., Xu, S., Mihaylova, M. M., Zheng, B., Hou, X., Jiang, B., et al. (2011). AMPK Phosphorylates and Inhibits SREBP activity to attenuate hepatic steatosis and atherosclerosis in diet-induced insulin-resistant mice. Cell Metab. 13, 376-388. doi: 10.1016/j.cmet.2011.03.009

Liao, S., Li, D., Hui, Z., McLachlan, C. S., and Zhang, Y. (2018). Metformin added to bosentan therapy in patients with pulmonary arterial hypertension associated with congenital heart defects: a pilot study. ERJ Open Res. 4, 00060-2018. doi: 10.1183/23120541.00060-2018

Liao, S., Li, D., Hui, Z., McLachlan, C. S., and Zhang, Y. (2019). Chronic dosing with metformin plus bosentan decreases in vitro pulmonary artery contraction from isolated arteries in adults with pulmonary hypertension. J. Cardiovasc. Thorac. Res. 11, 189-195. doi: 10.15171/jcvtr.2019.32

Liu, Y., Xu, Y., Zhu, J., Li, H., Zhang, J., Yang, G., et al. (2019). Metformin prevents progression of experimental pulmonary hypertension via inhibition of autophagy and activation of adenosine monophosphate-activated protein kinase. J. Vascul. Res. 56, 117-128. doi: 10.1159/000498894

Lizcano, J. M., Göransson, O., Toth, R., Deak, M., Morrice, N. A., Boudeau, J., et al. (2004). LKB1 is a master kinase that activates 13 kinases of the AMPK subfamily, including MARK/PAR-1. EMBO J. 23, 833-843. doi: 10.1038/sj. emboj.7600110

Lv, Y., Tang, L.-L., Wei, J.-K., Xu, X.-F., Gu, W., Fu, L.-C., et al. (2013). Decreased Kv1.5 expression in intrauterine growth retardation rats with exaggerated pulmonary hypertension. Am. J. Physiol. Lung Cell. Mol. Physiol. 305:L856.

Lyle, M. A., Davis, J. P., and Brozovich, F. V. (2017). Regulation of pulmonary vascular smooth muscle contractility in pulmonary arterial hypertension: implications for therapy. Front. Physiol. 8:614-614.

Ma, H., Wang, J., Thomas, D. P., Tong, C., Leng, L., Wang, W., et al. (2010). Impaired macrophage migration inhibitory factor-AMP-activated protein kinase activation and ischemic recovery in the senescent heart. Circulation 122, 282-292. doi: 10.1161/circulationaha.110.953208

Madden, J. A., Dawson, C. A., and Harder, D. R. (1985). Hypoxia-induced activation in small isolated pulmonary arteries from the cat. J. Appl. Physiol. 59, 113-118. doi: 10.1152/jappl.1985.59.1.113

Madden, J. A., Vadula, M. S., and Kurup, V. P. (1992). Effects of hypoxia and other vasoactive agents on pulmonary and cerebral artery smooth muscle cells. Am. J. Physiol. Lung Cell. Mol. Physiol. 263, L384-L393.

Maron, B. A., and Galiè, N. (2016). Diagnosis, treatment, and clinical management of pulmonary arterial hypertension in the contemporary era: a review. JAMA Cardiol. 1, 1056-1065. doi: 10.1001/jamacardio.2016.4471

Maron, B. A., and Leopold, J. A. (2015). Emerging concepts in the molecular basis of pulmonary arterial hypertension: part II: neurohormonal signaling contributes to the pulmonary vascular and right ventricular pathophenotype of pulmonary arterial hypertension. Circulation 131, 2079-2091. doi: 10.1161/ circulationaha.114.006980

Marsin, A. S., Bertrand, L., Rider, M. H., Deprez, J., Beauloye, C., Vincent, M. F., et al. (2000). Phosphorylation and activation of heart PFK-2 by AMPK has a role in the stimulation of glycolysis during ischaemia. Curr. Biol. 10, 1247-1255. doi: 10.1016/s0960-9822(00)00742-9

McMurtry, I. F., Davidson, A. B., Reeves, J. T., and Grover, R. F. (1976). Inhibition of hypoxic pulmonary vasoconstriction by calcium antagonists in isolated rat lungs. Circulat. Res. 38, 99-104. doi: 10.1161/01.res.38.2.99

Mihaylova, M. M., and Shaw, R. J. (2011). The AMPK signalling pathway coordinates cell growth, autophagy and metabolism. Nat. Cell Biol. 13, 10161023. doi: $10.1038 / \mathrm{ncb} 2329$

Miller, E. J., Li, J., Leng, L., McDonald, C., Atsumi, T., Bucala, R., et al. (2008). Macrophage migration inhibitory factor stimulates AMP-activated protein kinase in the ischaemic heart. Nature 451, 578-582. doi: 10.1038/nature06504

Momcilovic, M., Hong, S.-P., and Carlson, M. (2006). Mammalian TAK1 activates Snf1 protein kinase in yeast and phosphorylates AMP-activated protein kinase in vitro. J. Biol. Chem. 281, 25336-25343. doi: 10.1074/jbc.m6043 99200

Moral-Sanz, J., Lewis, S. A., MacMillan, S., Ross, F. A., Thomson, A., Viollet, B., et al. (2018). The LKB1-AMPK- $\alpha 1$ signaling pathway triggers hypoxic pulmonary vasoconstriction downstream of mitochondria. Sci. Signal. 11:0296.

Moral-Sanz, J., Mahmoud, A. D., Ross, F. A., Eldstrom, J., Fedida, D., Hardie, D. G., et al. (2016). AMP-activated protein kinase inhibits Kv 1.5 channel currents of pulmonary arterial myocytes in response to hypoxia and inhibition of mitochondrial oxidative phosphorylation. J. Physiol. 594, 4901-4915. doi: 10.1113/jp272032

Morrison, A., Yan, X., Tong, C., and Li, J. (2011). Acute rosiglitazone treatment is cardioprotective against ischemia-reperfusion injury by modulating AMPK, Akt, and JNK signaling in nondiabetic mice. Am. J. Physiol. Heart Circulat. Physiol. 301, H895-H902.

Moudgil, R., Michelakis, E. D., and Archer, S. L. (2005). Hypoxic pulmonary vasoconstriction. J. Appl. Physiol. 98, 390-403.

Munday, M. R., Campbell, D. G., Carling, D., and Hardie, D. G. (1988). Identification by amino acid sequencing of three major regulatory phosphorylation sites on rat acetyl-CoA carboxylase. Eur. J. Biochem. 175, 331-338. doi: 10.1111/j.1432-1033.1988.tb14201.x

Mungai, P. T., Waypa, G. B., Jairaman, A., Prakriya, M., Dokic, D., Ball, M. K., et al. (2011). Hypoxia triggers AMPK Activation through reactive oxygen speciesmediated activation of calcium release-activated calcium channels. Mol. Cell. Biol. 31, 3531-3545. doi: 10.1128/mcb.05124-11

Murray, T. R., Chen, L., Marshall, B. E., and Macarak, E. J. (1990a). Hypoxic contraction of cultured pulmonary vascular smooth muscle cells. Am. J. Respirat. Cell Mol. Biol. 3, 457-465. doi: 10.1165/ajrcmb/3.5.457

Murray, T. R., Marshall, B. E., and Macarak, E. J. (1990b). Contraction of vascular smooth muscle in cell culture. J. Cell. Physiol. 143, 26-38. doi: 10.1007/978-3642-66427-4_6

Myers, R. W., Guan, H.-P., Ehrhart, J., Petrov, A., Prahalada, S., Tozzo, E., et al. (2017). pan-AMPK activator MK-8722 improves glucose homeostasis but induces cardiac hypertrophy. Science 357, 507-511. doi: 10.1126/science. aah5582

Nagata, D., Kiyosue, A., Takahashi, M., Satonaka, H., Tanaka, K., Sata, M., et al. (2009). A new constitutively active mutant of AMP-activated protein kinase inhibits anoxia-induced apoptosis of vascular endothelial cell. Hypertens. Res. 32, 133-139. doi: 10.1038/hr.2008.25

Nicolls, M. R., and Voelkel, N. F. (2017). The roles of immunity in the prevention and evolution of pulmonary arterial hypertension. Am. J. Respirat. Crit. Care Med. 195, 1292-1299. doi: 10.1164/rccm.201608-1630pp

Oakhill, J. S., Chen, Z.-P., Scott, J. W., Steel, R., Castelli, L. A., Ling, N., et al. (2010). $\beta$-Subunit myristoylation is the gatekeeper for initiating metabolic stress sensing by AMP-activated protein kinase (AMPK). Proc. Natl. Acad. Sci. U.S.A. 107, 19237-19241. doi: 10.1073/pnas.100970 5107

Oakhill, J. S., Scott, J. W., and Kemp, B. E. (2012). AMPK functions as an adenylate charge-regulated protein kinase. Trends Endocrinol. Metabol. 23, 125-132. doi: 10.1016/j.tem.2011.12.006 
Omura, J., Satoh, K., Kikuchi, N., Satoh, T., Kurosawa, R., Nogi, M., et al. (2016). Protective roles of endothelial AMP-activated protein kinase against hypoxiainduced pulmonary hypertension in mice. Circulat. Res. 119, 197-209. doi: 10.1161/circresaha.115.308178

Park, J. W., Lee, J. H., Park, Y. H., Park, S. J., Cheon, J. H., Kim, W. H., et al. (2017). Sex-dependent difference in the effect of metformin on colorectal cancerspecific mortality of diabetic colorectal cancer patients. World J. Gastroenterol. 23, 5196-5205. doi: 10.3748/wjg.v23.i28.5196

Penaloza, D., and Arias-Stella, J. (2007). The heart and pulmonary circulation at high altitudes. Circulation 115, 1132-1146. doi: 10.1161/circulationaha.106. 624544

Plecitá-Hlavatá, L., Tauber, J., Li, M., Zhang, H., Flockton, A. R., Pullamsetti, S. S., et al. (2016). Constitutive reprogramming of fibroblast mitochondrial metabolism in pulmonary hypertension. Am. J. Respirat. Cell Mol. Biol. 55, 47-57. doi: 10.1165/rcmb.20150142 oc

Quan, H., Zhang, H., Wei, W., and Fang, T. (2016). Gender-related different effects of a combined therapy of Exenatide and Metformin on overweight or obesity patients with type 2 diabetes mellitus. J. Diab. Complicat. 30, 686-692. doi: 10.1016/j.jdiacomp.2016.01.013

Rabinovitch, M., Guignabert, C., Humbert, M., and Nicolls, M. R. (2014). Inflammation and immunity in the pathogenesis of pulmonary arterial hypertension. Circulat. Res. 115, 165-175. doi: 10.1161/circresaha.113. 301141

Rana, U., Callan, E., Entringer, B., Michalkiewicz, T., Joshi, A., Parchur, A. K., et al. (2020). AMP-kinase dysfunction alters notch ligands to impair angiogenesis in neonatal pulmonary hypertension. Am. J. Respirat. Cell Mol. Biol. 62, 719-731. doi: 10.1165/rcmb.2019-0275oc

Ranchoux, B., Harvey, L. D., Ayon, R. J., Babicheva, A., Bonnet, S., Chan, S. Y., et al. (2018). Endothelial dysfunction in pulmonary arterial hypertension: an evolving landscape (2017 Grover Conference Series). Pulmon. Circulat. 8:2045893217752912.

Robertson, T. P., Mustard, K. J., Lewis, T. H., Clark, J. H., Wyatt, C. N., Blanco, E. A., et al. (2008). AMP-activated protein kinase and hypoxic pulmonary vasoconstriction. Eur. J. Pharmacol. 595, 39-43. doi: 10.1016/j.ejphar.2008. 07.035

Rojas, J., Arraiz, N., Aguirre, M., Velasco, M., and Bermúdez, V. (2011). AMPK as target for intervention in childhood and adolescent obesity. Int. J. Obesit. 2011, 252817-252817.

Ross, F. A., Jensen, T. E., and Hardie, D. G. (2016a). Differential regulation by AMP and ADP of AMPK complexes containing different $\gamma$ subunit isoforms. Biochem. J. 473, 189-199. doi: 10.1042/bj20150910

Ross, F. A., MacKintosh, C., and Hardie, D. G. (2016b). AMP-activated protein kinase: a cellular energy sensor that comes in 12 flavours. FEBS J. 283, 29873001. doi: $10.1111 /$ febs.13698

Ruderman, N. B., Park, H., Kaushik, V. K., Dean, D., Constant, S., Prentki, M., et al. (2003). AMPK as a metabolic switch in rat muscle, liver and adipose tissue after exercise. Acta Physiol. Scand. 178, 435-442. doi: 10.1046/j.1365201x.2003.01164.x

Russell, R. R. I. I. I., Li, J., Coven, D. L., Pypaert, M., Zechner, C., Palmeri, M., et al. (2004). AMP-activated protein kinase mediates ischemic glucose uptake and prevents postischemic cardiac dysfunction, apoptosis, and injury. J. Clin. Investigat. 114, 495-503. doi: 10.1172/jci 19297

Rutter, G. A., da Silva Xavier, G., and Leclerc, I. (2003). Roles of 5' -AMP-activated protein kinase (AMPK) in mammalian glucose homoeostasis. Biochem. J. 375, 1-16. doi: 10.1042/bj20030048

Ryan, J. J., Marsboom, G., and Archer, S. L. (2013). Rodent models of group 1 pulmonary hypertension. Handbook Exp. Pharmacol. 218, 105-149. doi: 10. 1007/978-3-662-45805-1_5

Sakamoto, K., McCarthy, A., Smith, D., Green, K. A., Hardie, D. G., Ashworth, A., et al. (2005). Deficiency of LKB1 in skeletal muscle prevents AMPK activation and glucose uptake during contraction. EMBO J. 24, 1810-1820. doi: 10.1038/ sj.emboj.7600667

Sakamoto, K., Zarrinpashneh, E., Budas, G. R., Pouleur, A. C., Dutta, A., Prescott, A. R., et al. (2006). Deficiency of LKB1 in heart prevents ischemia-mediated activation of AMPKalpha2 but not AMPKalpha1. Am. J. Physiol. Endocrinol. Metabol. 290, E780-E788.
Sakao, S., and Tatsumi, K. (2011). The effects of antiangiogenic compound SU5416 in a rat model of pulmonary arterial hypertension. Respirat. Int. Rev. Thorac. Dis. 81, 253-261. doi: 10.1159/000322011

Sallé-Lefort, S., Miard, S., Nolin, M.-A., Boivin, L., Paré, M. -È, Debigaré, R., et al. (2016). Hypoxia upregulates Malat1 expression through a CaMKK/AMPK/HIF- $1 \alpha$ axis. Int. J. Oncol. 49, 1731-1736. doi: 10.3892/ijo. 2016.3630

Satoh, K., Fukumoto, Y., Nakano, M., Sugimura, K., Nawata, J., Demachi, J., et al. (2009). Statin ameliorates hypoxia-induced pulmonary hypertension associated with down-regulated stromal cell-derived factor-1. Cardiovasc. Res. 81, 226234. doi: $10.1093 / \mathrm{cvr} / \mathrm{cvn} 244$

Schoental, R., and Head, M. A. (1955). Pathological changes in rats as a result of treatment with monocrotaline. Br. J. Cancer 9, 229-237. doi: 10.1038/bjc. 1955.19

Scott, J. W., Norman, D. G., Hawley, S. A., Kontogiannis, L., and Hardie, D. G. (2002). Protein kinase substrate recognition studied using the recombinant catalytic domain of AMP-activated protein kinase and a model substrate. J. Mol. Biol. 317, 309-323. doi: 10.1006/jmbi.2001.5316

Shackelford, D. B., and Shaw, R. J. (2009). The LKB1-AMPK pathway: metabolism and growth control in tumour suppression. Nat. Rev. Cancer 9, 563-575. doi: $10.1038 / \mathrm{nrc} 2676$

Shaw, R. J., Kosmatka, M., Bardeesy, N., Hurley, R. L., Witters, L. A., DePinho, R. A., et al. (2004). The tumor suppressor LKB1 kinase directly activates AMPactivated kinase and regulates apoptosis in response to energy stress. Proc. Natl. Acad. Sci. U.S.A. 101, 3329-3335. doi: 10.1073/pnas.0308061100

Shaw, R. J., Lamia, K. A., Vasquez, D., Koo, S. H., Bardeesy, N., Depinho, R. A., et al. (2005). The kinase LKB1 mediates glucose homeostasis in liver and therapeutic effects of metformin. Science 310, 1642-1646. doi: 10.1126/science.11 20781

Shimoda, L. A., and Laurie, S. S. (2013). Vascular remodeling in pulmonary hypertension. J. Mol. Med. 91, 297-309.

Shirwany, N. A., and Zou, M. H. (2010). AMPK in cardiovascular health and disease. Acta Pharmacol. Sin. 31, 1075-1084. doi: 10.1038/aps.2010.139

Simonneau, G., Montani, D., Celermajer, D. S., Denton, C. P., Gatzoulis, M. A., Krowka, M., et al. (2019). Haemodynamic definitions and updated clinical classification of pulmonary hypertension. Eur. Respirat. J. 53:1801913. doi: 10. 1183/13993003.01913-2018

Sommer, N., Dietrich, A., Schermuly, R. T., Ghofrani, H. A., Gudermann, T., Schulz, R., et al. (2008). Regulation of hypoxic pulmonary vasoconstriction: basic mechanisms. Eur. Respirat. J. 32, 1639-1651.

Song, Y., Wu, Y., Su, X., Zhu, Y., Liu, L., Pan, Y., et al. (2016). Activation of AMPK inhibits PDGF-induced pulmonary arterial smooth muscle cells proliferation and its potential mechanisms. Pharmacol. Res. 107, 117-124. doi: 10.1016/j. phrs.2016.03.010

Stapleton, D., Mitchelhill, K. I., Gao, G., Widmer, J., Michell, B. J., Teh, T., et al. (1996). Mammalian AMP-activated protein kinase subfamily. J. Biol. Chem. 271, 611-614.

Stenmark, K. R., and McMurtry, I. F. (2005). Vascular remodeling versus vasoconstriction in chronic hypoxic pulmonary hypertension. Circul. Res. 97, 95-98. doi: 10.1161/01.res.00000175934.68087.29

Stenmark, K. R., Fagan, K. A., and Frid, M. G. (2006). Hypoxia-induced pulmonary vascular remodeling. Circulat. Res. 99, 675-691.

Sun, Z., Liu, Y., Yu, F., Xu, Y., Yanli, L., and Liu, N. (2019). Long noncoding RNA and mRNA profile analysis of metformin to reverse the pulmonary hypertension vascular remodeling induced by monocrotaline. Biomed. Pharmacother. 115:108933. doi: 10.1016/j.biopha.2019.108933

Sylvester, J. T., Shimoda, L. A., Aaronson, P. I., and Ward, J. P. T. (2012). Hypoxic pulmonary vasoconstriction. Physiol. Rev. 92, 367-520.

Sztuka, K., and Jasiñska-Stroschein, M. (2017). Animal models of pulmonary arterial hypertension: a systematic review and meta-analysis of data from 6126 animals. Pharmacol. Res. 125, 201-214. doi: 10.1016/j.phrs.2017.08.003

Taraseviciene-Stewart, L., Kasahara, Y., Alger, L., Hirth, P., Mc Mahon, G., Waltenberger, J., et al. (2001). Inhibition of the VEGF receptor 2 combined with chronic hypoxia causes cell death-dependent pulmonary endothelial cell proliferation and severe pulmonary hypertension. FASEB J. 15, 427-438. doi: 10.1096/fj.00-0343com

Tarry, D., and Powell, M. (2017). Hypoxic pulmonary vasoconstriction. BJA Educat. 17, 208-213. 
Teng, R.-J., Du, J., Afolayan, A. J., Eis, A., Shi, Y., and Konduri, G. G. (2013). AMP kinase activation improves angiogenesis in pulmonary artery endothelial cells with in utero pulmonary hypertension. Am. J. Physiol. Lung Cell. Mol. Physiol. 304, L29-L42.

Thenappan, T., Ormiston, M. L., Ryan, J. J., and Archer, S. L. (2018). Pulmonary arterial hypertension: pathogenesis and clinical management. BMJ 360:j5492. doi: $10.1136 /$ bmj.j5492

Thenappan, T., Shah, S. J., Gomberg-Maitland, M., Collander, B., Vallakati, A., Shroff, P., et al. (2011). Clinical characteristics of pulmonary hypertension in patients with heart failure and preserved ejection fraction. Circulat. Heart Fail. 4, 257-265.

Thomson, D. M., Porter, B. B., Tall, J. H., Kim, H.-J., Barrow, J. R., and Winder, W. W. (2007). Skeletal muscle and heart LKB1 deficiency causes decreased voluntary running and reduced muscle mitochondrial marker enzyme expression in mice. Am. J. Physiol. Endocrinol. Metab. 292, E196-E202.

Towler, M. C., and Hardie, D. G. (2007). AMP-activated protein kinase in metabolic control and insulin signaling. Circulat. Res. 100, 328-341. doi: 10.1161/01.res.0000256090.42 690.05

Toyama, E. Q., Herzig, S., Courchet, J., Lewis, T. L., Losón, O. C., Hellberg, K., et al. (2016). AMP-activated protein kinase mediates mitochondrial fission in response to energy stress. Science 351, 275-281. doi: 10.1126/science.aab4138

Tuder, R. M. (2017). Pulmonary vascular remodeling in pulmonary hypertension. Cell Tissue Res. 367, 643-649.

Tuder, R. M., Marecki, J. C., Richter, A., Fijalkowska, I., and Flores, S. (2007). Pathology of pulmonary hypertension. Clin. Chest Med. 28, 23-vii.

Viollet, B., Lantier, L., Devin-Leclerc, J., Hebrard, S., Amouyal, C., Mounier, R., et al. (2009). Targeting the AMPK pathway for the treatment of Type 2 diabetes. Front. Biosci. (Landmark Ed.) 14:3380-3400. doi: 10.2741/3460

von Euler, U. S., and von Liljestrand, G. (1946). Observations on the pulmonary arterial blood pressure in the cat. Acta Physiol. Scandinav. 12, 301-320. doi: 10.1111/j.1748-1716.1946.tb00389.x

Wang, L., Halliday, G., Huot, J. R., Satoh, T., Baust, J. J., Fisher, A., et al. (2020). Treatment with treprostinil and metformin normalizes hyperglycemia and improves cardiac function in pulmonary hypertension associated with heart failure with preserved ejection fraction. Arterioscl. Thromb. Vascul. Biol. 40, 1543-1558. doi: 10.1161/atvbaha.119.313883

Wang, Y. -g., Han, X.-g., Yang, Y., Qiao, H., Dai, K. -r., Fan, Q. -m., et al. (2016). Functional differences between AMPK $\alpha 1$ and $\alpha 2$ subunits in osteogenesis, osteoblast-associated induction of osteoclastogenesis, and adipogenesis. Sci. Rep. 6:32771.

Wang, Z., Wilson, W. A., Fujino, M. A., and Roach, P. J. (2001). Antagonistic controls of autophagy and glycogen accumulation by Snflp, the yeast homolog of AMP-activated protein kinase, and the cyclin-dependent kinase Pho85p. Mol. Cell. Biol. 21, 5742-5752. doi: 10.1128/mcb.21.17.5742-5752. 2001

Waypa, G. B., and Schumacker, P. T. (2010). Hypoxia-induced changes in pulmonary and systemic vascular resistance: where is the $\mathrm{O} 2$ sensor. Respirat. Physiol. Neurobiol. 174, 201-211. doi: 10.1016/j.resp.2010.08.007

Weir, E. K., and Archer, S. L. (1995). The mechanism of acute hypoxic pulmonary vasoconstriction: the tale of two channels. FASEB J. 9, 183-189. doi: 10.1096/ fasebj.9.2.7781921

Wilson, D. W., Segall, H. J., Pan, L. C., and Dunston, S. K. (1989). Progressive inflammatory and structural changes in the pulmonary vasculature of monocrotaline-treated rats. Microvasc. Res. 38, 57-80. doi: 10.1016/00262862(89)90017-4

Woods, A., Dickerson, K., Heath, R., Hong, S. P., Momcilovic, M., Johnstone, S. R., et al. (2005). Ca2+/calmodulin-dependent protein kinase kinase-beta acts upstream of AMP-activated protein kinase in mammalian cells. Cell Metab. 2, 21-33. doi: 10.1016/j.cmet.2005.06.005

Woods, A., Johnstone, S. R., Dickerson, K., Leiper, F. C., Fryer, L. G., Neumann, D., et al. (2003). LKB1 is the upstream kinase in the AMP-activated protein kinase cascade. Curr. Biol. 13, 2004-2008. doi: 10.1016/j.cub.2003. 10.031

Wu, N., Zheng, B., Shaywitz, A., Dagon, Y., Tower, C., Bellinger, G., et al. (2013). AMPK-dependent degradation of TXNIP upon energy stress leads to enhanced glucose uptake via GLUT1. Mol. Cell 49, 1167-1175. doi: 10.1016/j.molcel.2013. 01.035

Wu, S., and Zou, M. H. (2020). AMPK, mitochondrial function, and cardiovascular disease. Int. J. Mol. Sci. 21:4987. doi: 10.3390/ijms21144987
Wu, Y., Liu, L., Zhang, Y., Wang, G., Han, D., Ke, R., et al. (2014). Activation of AMPK inhibits pulmonary arterial smooth muscle cells proliferation. Exp. Lung Res. 40, 251-258. doi: 10.3109/01902148.2014.913092

Wu, Y., Song, P., Zhang, W., Liu, J., Dai, X., Liu, Z., et al. (2015). Activation of AMPK $\alpha 2$ in adipocytes is essential for nicotine-induced insulin resistance in vivo. Nat. Med. 21, 373-382. doi: 10.1038/nm.3826

Xiao, B., Heath, R., Saiu, P., Leiper, F. C., Leone, P., Jing, C., et al. (2007). Structural basis for AMP binding to mammalian AMP-activated protein kinase. Nature 449, 496-500. doi: 10.1038/nature06161

Xiao, B., Sanders, M. J., Underwood, E., Heath, R., Mayer, F. V., Carmena, D., et al. (2011). Structure of mammalian AMPK and its regulation by ADP. Nature 472, 230-233. doi: 10.1038/nature09932

Xue, J., Nelin, L. D., and Chen, B. (2017). Hypoxia induces arginase II expression and increases viable human pulmonary artery smooth muscle cell numbers via AMPK $\alpha 1$ signaling. Am. J. Physiol. Lung Cell. Mol. Physiol. 312, L568-L578.

Yan, H., Zhang, D. X., Shi, X., Zhang, Q., and Huang, Y. S. (2012). Activation of the prolyl-hydroxylase oxygen-sensing signal cascade leads to AMPK activation in cardiomyocytes. J. Cell. Mol. Med. 16, 2049-2059. doi: 10.1111/j.1582-4934. 2011.01500.x

Yan, Y., Zhou, X. E., Xu, H. E., and Melcher, K. (2018). Structure and physiological regulation of AMPK. Int. J. Mol. Sci. 19:3534. doi: 10.3390/ijms19113534

Yoshida, T., Matsuura, K., Goya, S., Ma, D., Shimada, K., Kitpipatkun, P., et al. (2020). Metformin prevents the development of monocrotaline-induced pulmonary hypertension by decreasing serum levels of big endothelin-1. Exp. Therap. Med. 20:149.

Yuan, J. X.-J., Aldinger, A. M., Juhaszova, M., Wang, J., Conte, J. V., Gaine, S. P., et al. (1998). Dysfunctional voltage-gated $\mathrm{K}+$ channels in pulmonary artery smooth muscle cells of patients with primary pulmonary hypertension. Circulation 98, 1400-1406. doi: 10.1161/01.cir.98.14.1400

Zarrinpashneh, E., Carjaval, K., Beauloye, C., Ginion, A., Mateo, P., Pouleur, A.C., et al. (2006). Role of the $\alpha 2$-isoform of AMP-activated protein kinase in the metabolic response of the heart to no-flow ischemia. Am. J. Physiol. Heart Circulat. Physiol. 291, H2875-H2883.

Zhai, C., Shi, W., Feng, W., Zhu, Y., Wang, J., Li, S., et al. (2018). Activation of AMPK prevents monocrotaline-induced pulmonary arterial hypertension by suppression of NF-кB-mediated autophagy activation. Life Sci. 208, 87-95. doi: $10.1016 /$ j.lfs.2018.07.018

Zhang, J., Dong, J., Martin, M., He, M., Gongol, B., Marin, T. L., et al. (2018). Shyy, AMP-activated protein kinase phosphorylation of angiotensin-converting enzyme 2 in endothelium mitigates pulmonary hypertension. Am. J. Respirat. Cell Mol. Biol. 198, 509-520. doi: 10.1164/rccm.201712-2570oc

Zhang, Y., Lee, T. S., Kolb, E. M., Sun, K., Lu, X., Sladek, F. M., et al. (2006). AMP-activated protein kinase is involved in endothelial NO synthase activation in response to shear stress. Arterioscler. Thromb. Vasc. Biol. 26, 1281-1287. doi: 10.1161/01.atv.0000221230.08596.98

Zhao, F., Wang, C., and Zhu, X. (2020). Isoform-specific roles of AMPK catalytic $\alpha$ subunits in Alzheimer's disease. J. Clin. Investigat. 130, 3403-3405. doi: $10.1172 /$ jci137908

Zhao, L. (2010). Chronic hypoxia-induced pulmonary hypertension in rat: the best animal model for studying pulmonary vasoconstriction and vascular medial hypertrophy. Drug Discover. Today Dis. Models 7, 83-88.

Zmijewski, J. W., Banerjee, S., Bae, H., Friggeri, A., Lazarowski, E. R., and Abraham, E. (2010). Exposure to hydrogen peroxide induces oxidation and activation of AMP-activated protein kinase. J. Biol. Chem. 285, 33154-33164. doi: 10.1074/ jbc.m110.143685

Zong, H., Ren, J. M., Young, L. H., Pypaert, M., Mu, J., Birnbaum, M. J., et al. (2002). AMP kinase is required for mitochondrial biogenesis in skeletal muscle in response to chronic energy deprivation. Proc. Natl. Acad. Sci. U.S.A. 99, 15983-15987. doi: 10.1073/pnas.252625599

Conflict of Interest: The authors declare that the research was conducted in the absence of any commercial or financial relationships that could be construed as a potential conflict of interest.

Copyright (c) 2021 Zhao, Song and Zou. This is an open-access article distributed under the terms of the Creative Commons Attribution License (CC BY). The use, distribution or reproduction in other forums is permitted, provided the original author(s) and the copyright owner(s) are credited and that the original publication in this journal is cited, in accordance with accepted academic practice. No use, distribution or reproduction is permitted which does not comply with these terms. 